\title{
A Teoria da Estrutura Hipotética das Normas Jurídicas de Kelsen - características, evolução e balanço de sua importância
}

\author{
Kelsen's Theory of the Hypothetical Structure \\ of Legal Norms - features, evolution and evalua- \\ tion of its importance
}

\section{Alexandre Travessoni Gomes Trivosonno ${ }^{1}$}

Resumo: este ensaio aborda a evolução da teoria de Kelsen sobre a estrutura das normas jurídicas no contexto da evolução de sua obra. São abordadas as principais ideias de Kelsen sobre os conceitos de norma e proposição jurídicas, bem como sobre a estrutura hipotética das autênticas normas jurídicas, que são aquelas que ligam, a determinados pressupostos fáticos, atos de coação como sanção - normas que Kelsen, ao longo de sua obra, denominou "normas primárias". As consequências dessa teoria, tais como a considera-

1 Doutor em Filosofia do Direito pela Universidade Federal de Minas Gerais. Realizou pesquisa de Pós-Doutorado no Instituto de Direito Público, Teoria da Constituição e Filosofia do Direito da Universidade de Heidelberg, em 2018/2019, com financiamento do DAAD, da Fundação Alexander von Humboldt e da Universidade de Heidelberg, sob supervisão do Prof. Dr. Martin Borowski, onde se encontra novamente como Pesquisador Convidado, desde fevereiro de 2020. Atualmente é Professor Adjunto III da Pontifícia Universidade Católica de Minas Gerais e Professor Titular da Universidade Federal de Minas Gerais, atuando nos programas de graduação e de pós-graduação em Direito 
ção das normas que enunciam os deveres ("normas secundárias" no linguajar kelseniano) como normas supérfluas e a crítica ao conceito e às teorias clássicas sobre o direito subjetivo também são brevemente abordadas. Após isso, é apresentada uma comparação entre a estrutura das normas em Kelsen e a distinção, elaborada por Hart, entre regras jurídicas primárias e secundárias. No final é apresentado um balanço crítico sobre a importância da teoria da estrutura hipotética das normas jurídicas desenvolvida por Kelsen.

Palavras-chave: Kelsen; norma jurídica; estrutura hipotética; dever jurídico.

Abstract: this essay handles the evolution of the theory of the structure of legal norms developed by Kelsen. It approaches Kelsen's main ideas about the concepts of legal norm and legal proposition, as well as about the hypothetical structure of the authentic legal norms, which are the ones that connect coercion acts to material facts - norms that Kelsen coined as "primary norms". The consequences of such approach - as the characterization of norms that formulate legal duties ("secondary norms" in Kelsen's parlance) as superfluous norms and Kelsen's criticism on the concept and on legal theories about subjective right are also briefly discussed. Afterwards a comparison between Kelsen's theory and Hart's distinction of primary and secondary rules is made. In the end, a critical analysis about the importance of Kelsen's theory of the hypothetical structure of the legal norms is presented.

Keywords: Kelsen; legal norm; hypothetical structure; legal duty. 


\section{Introdução}

O conceito positivista de direito de Kelsen se caracteriza pela separação do direito tanto da moral (e de um suposto direito natural) quanto dos fatos. Exatamente por isso a teoria do direito de Kelsen é uma teoria pura, o que não quer dizer, naturalmente, que o direito, em Kelsen, o seja. ${ }^{2}$

A pureza e a definição do direito como ordem coativa repercutem na concepção de Kelsen sobre o conceito e a estrutura das normas jurídicas, bem como nos conceitos de dever jurídico e direito subjetivo.

Como veremos abaixo, o conceito e a tipologia das normas jurídicas - embora tenham sido objeto de evolução na teoria de Kelsen - apresentam um núcleo comum desde sua primeira obra na área de Teoria de Direito, sua Tese de Habilitação Principais Problemas da Teoria Jurídica do Estado, Desenvolvidos com Base na Teoria da Proposição Jurídica ${ }^{3}$ (que, de agora em diante será denominada apenas como Principais Problemas), publicada em 1911, até a Teoria Geral das Normas, ${ }^{4}$ publicada em 1979, portanto após a morte de Kelsen. Como se perceberá, apesar de haver evolução da teoria da estrutura das normas jurídicas desenvolvida por Kelsen, a ideia de que a norma jurídica autêntica é aquela que liga um ato de coação a determinado pressuposto permanece inalterada em toda sua obra.

Para se compreender a essência e a evolução da teoria da estrutura hipotética das normas jurídicas defendida por Kelsen é necessário começar abordando uma importante distinção: a distinção entre norma e proposição jurídica, o

2 Sobre a pureza da Teoria Pura do Direito cf. KOJA, Hans Kelsen oder die Reinheit der Rechtslehre.

3 KELSEN, Hauptprobleme der Staatsrechtslehre.

4 KELSEN, Allgemeine Theorie der Normen. 
que será feito na seção 2. Após isso será analisada, com um certo detalhamento, a teoria da estrutura hipotética das normas jurídicas nas principais obras de Kelsen (seção 3). ${ }^{5}$ Será realizada, então, na seção 4, uma breve comparação entre as teorias de Kelsen e Hart sobre a estrutura das normas jurídicas (em Hart, tipos de regras jurídicas), apresentadando posteriromente algumas observações conclusivas, que se concentrarão sobretudo na importância, atualmente, da teoria da estrutura hipotética das normas jurídicas defendida por Kelsen.

\section{Norma e Proposição Jurídica}

A relação entre norma e proposição jurídica é bastante controversa na obra de Kelsen. Se, por um lado, a partir da década de 1940, mais precisamente a partir de 1941, Kelsen diferencia com certa clareza a norma e a proposição jurídica, por outro lado, há uma certa polêmica sobre se e em que medida Kelsen distingue esses dois conceitos em seus escritos

$5 \quad$ A análise desenvolvida neste ensaio será limitada às principais obras monográficas de Kelsen: Principais Problemas, Teoria Geral do Estado, $1^{\text {a }}$ edição (alemã) da Teoria Pura do Direito, Teoria Geral do Direito e do Estado, versão francesa da $1^{a}$ edição da Teoria Pura do Direito, $2^{a}$ edição da Teoria Pura do Direito e Teoria Geral das Normas. Embora Kelsen tenha escrito inúmeros artigos, alguns dos jurídicas, o estudo das obras mencionadas é capaz de fornecer um panorama geral bastante amplo. Citarei as obras de Kelsen da seguinte forma: (i) no caso de Principais Problemas, da Teoria Geral do Estado, da $1^{a}$ edição (alemã) da Teoria Pura do Direito, da versão francesa da $1^{\text {a }}$ edição da Teoria Pura do Direito, do artigo O Professor Stone e a Teoria Pura do Direito e do artigo A Teoria Pura do Direito e a Jurisprudência Analítica as citações são extraídas dos respectivos originais, e as traduções são minhas; (ii) no caso da Teoria Geral do Direito e do Estado, da 2a edição da Teoria Pura do Direito e da Teoria Geral das Normas, as citações são extraídas das traduções em língua portuguesa, sendo aposta a referência bibliográfica da obra original citada imediatamente antes da referência da obra traduzida. Eventualmente, no segundo caso, a tradução é por mim alterada; quando isso ocorre, há menção expressa. 
iniciais - embora o próprio Kelsen afirme, em seus trabalhos mais recentes, que sempre os diferenciou. ${ }^{6}$

Nos escritos iniciais de Kelsen, a proposição jurídica parece não se diferenciar com clareza da norma jurídica (primária) ou, pelo menos, não parece existir entre elas uma distinção epistêmico-ontológica. A proposição jurídica seria uma espécie de reconstrução, por parte da ciência do direito, das normas jurídicas ou, mais precisamente, uma reconstrução do material jurídico-positivo para se chegar à verdadeira norma jurídica (a norma primária) que, como se perceberá ao longo deste ensaio, é, para Kelsen, a norma que liga uma sanção a determinado pressuposto fático. ${ }^{7}$ Essa identificação relativa entre norma primária e proposição jurídica fica evidente na primeira edição da Teoria Pura do Direito, quando Kelsen afirma que somente a "proposição jurídica" pode enunciar o conteúdo do direito, a saber, que mediante a prática de determinada conduta deve ocorrer um ato coativo como consequência. ${ }^{8}$

A partir de 1941, no artigo A Teoria Pura do Direito e a Jurisprudência Analítica, ${ }^{9}$ Kelsen passa a diferenciar expressamente norma e proposição jurídica:

6 Trata-se do artigo O Professor Stone e a Teoria Pura do Direito, publicado em 1965: “A fim de evitar confusão entre normas jurídicas que prescrevem um certo comportamento humano e afirmações feitas pela ciência do direito descrevendo normas jurídicas, eu sugeri falar-se, no último caso, de Rechts-Satz como algo distinto de Rechts-Norm. Essa foi uma sugestão meramente terminológica. Eu nunca confundi a norma jurídica e as afirmações da ciência do direito, cujo objeto são as normas jurídicas. Já em meus Principais Problemas da Teoria Jurídica do Estado (1911), eu distingui o direito, ou seja, normas cuja essência é estipular que algo deve ser feito, e a ciência do direito, cujo objeto são normas." Cf. KELSEN, Professor Stone and the Pure Theory of Law, p. 1132.

7 A esse respeito, cf. HEIDEMANN, Die Norm als Tatsache-zur Normentheorie Hans Kelsens, p. 41.

8 KELSEN, Reine Rechtslehre, 1. Auflage, p. 30-31.

9 KELSEN, The Pure Theory of Law and Analytical Jurisprudence. 
Se a ciência do direito deve apresentar o direito como um sistema de normas válidas, as proposições através das quais ela descreve seu objeto devem ser proposições de 'dever ser', afirmações nas quais um 'dever ser', não um 'ser', é expressado. Mas as proposições da ciência do direito não são, elas mesmas, normas. Elas não estabelecem deveres ou direitos. Normas através das quais os indivíduos são obrigados e autorizados a exercer um poder emanam apenas da autoridade que cria o direito. O jurista, como expoente teórico do direito, apresenta essas normas em proposições que possuem um sentido meramente descritivo, afirmações que apenas descrevem o 'dever ser' da norma jurídica. É muito importante distinguir claramente normas jurídicas que constituem o objeto da ciência do direito e as afirmações da ciência do direito que descrevem esse objeto. ${ }^{10}$ (grifos acrescidos)

Depois disso essa distinção expressa passa a estar presente nas principais obras de Kelsen. ${ }^{11}$ Muito mais a respeito desse tema poderia ser dito. Mas isso extrapolaria os limites deste trabalho. De todo modo, a distinção entre norma e proposição jurídica reaparecerá ao longo do estudo que realizo a seguir.

10 KELSEN, The Pure Theory of Law and Analytical Jurisprudence, p. 51. Sobre a repercussão dessa suposta mudança de posição na periodização das obras de Kelsen cf. HEIDEMANN, Die Norm als Tatsache - zur Normentheorie Hans Kelsens, p. 41, bem como PAULSON, Four Phases in Kelsen's Pure Theory of Law?, p. 162; PAULSON, Reflexões sobre a Periodização da Teoria do Direito de Hans Kelsen - Com Pós-Escrito Inédito, p. 18. A periodização das obras de Kelsen é polêmica, mas a maioria dos intérpretes de Kelsen afirma haver, depois de 1960, uma ruptura na Teoria Pura do Direito (cf. por exemplo PAULSON, Kelsen's Legal Theory: the Final Round). Entendo que essa tese, embora praticamente unânime, não é correta. Não cabe, porém, aqui, discutí-la.

11 Essa distinção aparece de forma clara, como veremos abaixo, na Teoria Geral do Direito e do Estado, na versão francesa da $1^{a}$ edição da Teoria Pura do Direito, na segunda edição da Teoria Pura do Direito e na Teoria Geral das Normas. 


\section{Características e Evolução da Teoria da Es- trutura das Normas Jurídicas no Curso da Evolução da Teoria Pura do Direito}

\subsection{Conceito de Direito e Estrutura das Normas em Principais Problemas}

Como vimos acima, em Principais Problemas, obra publicada em 1911, Kelsen parece identificar norma e proposição jurídica. Além disso, ele critica a identificação das normas jurídicas como imperativos dirigidos aos cidadãos pois, em sua opinião, um imperativo é a expressão imediata de uma vontade psicológica, o que uma norma não é ${ }^{12} \mathrm{e}$ apresenta uma ideia fundamental que estará presente em todo desenvolvimento de sua obra: o ato antijurídico (ou ilícito) não constitui uma "exceção" ao direito, sendo antes um caso de aplicação da norma jurídica. Segundo Kelsen, somente com a antijuridicidade a ordem jurídica cumpre a sua função. ${ }^{13}$ Essa ideia é central para a concepção de que a autêntica norma jurídica é aquela que estabelece um ato de coação como sanção.

Ainda em Principais Problemas, Kelsen afirma que a proposição jurídica, em virtude de sua conexão com a ideia de obrigação, deve contar com uma "cláusula de aplicação": os imperativos "não mate" e "pague suas dívidas" oferecem uma possibilidade de cumprimento subjetivo, mas não uma possibilidade específica de aplicação, deixando por isso sem solução o problema de como pode surgir, a partir da norma objetiva, um dever jurídico subjetivo. A solução para esse problema, segundo Kelsen, só pode ser obtida através da fórmula da proposição jurídica como juízo hipotético - que

12 KELSEN, Hauptprobleme der Staatsrechtslehre, p. 210.

13 KELSEN, Hauptprobleme der Staatsrechtslehre, p. 349. 
contem a "vontade" do estado ${ }^{14}$ - e que determina que um determinado pressuposto fático-jurídico (Tatbestand) deve ser seguido de uma desvantagem. ${ }^{15}$ Nessa ideia de ligação de consequências jurídicas a pressupostos fáticos consiste o conceito de imputação (Zurechnung). ${ }^{16}$

Com base nessa identificação do direito como ordem coativa, Kelsen realiza uma ampla crítica ao conceito de direito subjetivo, afirmando que ele pode ser derivado da proposição jurídica (em sentido estrito). ${ }^{17}$ Essa crítica marcará todo o desenvolvimento de sua obra.

\subsection{Normas Primária e Secundária na Teoria Geral do}

\section{Estado}

Na Teoria Geral do Estado, publicada em 1925, Kelsen novamente identifica o direito como ordem normativa de coação $^{18}$ - na medida em que a determinados pressupostos jurídicos são ligados atos de coação como sanção,$-{ }^{19}$ faz uma crítica profunda à ideia de direito subjetivo e - o que é especialmente importante para este ensaio - afirma que a norma primária é aquela que liga um ato de coação a uma condição, enquanto a norma secundária é aquela que estabelece o comportamento que evita a sanção. A norma secundária é, nas palavras de Kelsen, apenas uma "construção auxiliar"

14 Vontade aqui não aparece em sentido psicológico, mas antes como conteúdo de normas jurídicas.

15 KELSEN, Hauptprobleme der Staatsrechtslehre, p. 349. Como já ressaltado acima, em Principais Problemas, norma jurídica (Rechtsnorm) e proposição jurídica (Rechtssatz) parecem possuir, pelo menos em alguns casos, o mesmo significado.

16 Que se diferencia tanto da causalidade natural quando de relações teleológicas. Cf. KELSEN, Hauptprobleme der Staatsrechtslehre, p. 75.

17 Cf. KELSEN, Hauptprobleme der Staatsrechtslehre, p. 618-629.

18 KELSEN, Allgemeine Staatslehre, p. 55-59.

19 KELSEN, Allgemeine Staatslehre, p. 47-50. 
(Hilfskonstruktion), que pode ser utilizada quando se identifica o direito com o estado, na medida em que ambos são concebidos como uma ordem coativa. ${ }^{20}$

\subsection{Sistematização de Conceitos Jurídicos Fundamen- tais e da Estrutura das Normas na Primeira Edição da Teoria Pura do Direito}

Na primeira edição da Teoria Pura do Direito, publicada em 1934, as considerações de Kelsen sobre a estrutura e a tipologia das normas jurídicas apresentam uma evolução considerável, na medida em que se conecta, de forma sistemática, a outros conceitos jurídicos fundamentais.

Kelsen identifica a proposição jurídica como uma espécie de proposição normativa obtida através da interpretação do material jurídico positivo, ao que parece identificando-a - como já havia feito em Principais Problemas - com a norma primária. Nesse sentido, Kelsen afirma:

Para ela [a Teoria Pura do Direito], a consequência que é conectada, na proposição jurídica, a uma determinada condição, é o ato de coação estatal, ou seja, a pena e a execução civil ou administrativa, com as quais o pressuposto fático condicionante é qualificado como antijurídico e o condicionado é qualificado como consequência do fato antijurídico.. ${ }^{21}$

Segundo Kelsen, essa concepção do direito como ordem coativa já estava presente na ciência do direito do século XIX. Porém, para ele, essa teoria não conseguiu chegar a algumas conclusões a que ela própria levaria, como, por exemplo, a mudança no conceito de antijuridicidade. ${ }^{22}$

20 KELSEN, Allgemeine Staatslehre, p. 52-53.

21 KELSEN, Reine Rechtslehre, 1. Auflage, p. 25-26.

22 KELSEN, Reine Rechtslehre, 1. Auflage, p. 26. Kelsen entende que, diante da conceituação da norma jurídica como a norma que liga um ato coativo 
A norma secundária surge a partir da ideia de que, em relação ao ordenamento jurídico, as pessoas devem se comportar de modo a evitar o ato coativo ligado pela proposição jurídica (a norma primária) a determinado ato condicionante. ${ }^{23}$ Nesse sentido, o ordenamento jurídico pode ser, para Kelsen, "resumido" como conjunto de normas dirigidas a essas condutas que evitam o ato coativo, normas como "não se deve matar", "deve-se pagar um empréstimo" etc. ${ }^{24}$ Porém, afirma Kelsen, quando se considera as normas secundárias, uma característica essencial do direito fica sem expressão: sua relação essencial com o ato coativo. ${ }^{25}$

Na visão de Kelsen, a norma jurídica secundária pode até ser adotada para fins de simplificação e comodidade, para expressar que não se deve praticar a conduta que leva à sanção. Contudo, como já mencionado, somente a "proposição jurídica" conseguiria enunciar de forma integral e correta o conteúdo do direito: mediante a prática de determinada conduta deve ocorrer um ato coativo como consequência. ${ }^{26}$ Essa

a uma condição, o conceito de antijuridicidade não pode continuar sendo definido como negação do direito, o que revelaria uma postura política. A antijuridicidade passa a ser compreendida como uma conduta determinada na proposição jurídica como condição do ato coativo nela estabelecido como consequência. Mas, como veremos abaixo, ao tratar do conceito de norma secundária, Kelsen admite um "certo" acerto na ideia de antijuridicidade como negação do direito (KELSEN, Reine Rechtslehre, 1. Auflage, p. 25-26).

23 KELSEN, Reine Rechtslehre, 1. Auflage, p. 30.

24 KELSEN, Reine Rechtslehre, 1. Auflage, p. 30.

25 KELSEN, Reine Rechtslehre, 1. Auflage, p. 30.

26 KELSEN, Reine Rechtslehre, 1. Auflage, p. 30-31. Kelsen destaca ainda que uma norma não necessariamente precisa ligar a sanção à pessoa que pratica a conduta, podendo, portanto, ligá-la a uma pessoa diversa. Tratase nesse caso, da pressuposição de um vínculo jurídico, real ou fictício, entre a pessoa que praticou o ato antijurídico e a pessoa a quem a sanção se dirige, ou, em outros termos, de "responsabilidade por uma conduta antijurídica alheia". Assim, uma norma (primária) pode determinar, por exemplo, que se uma pessoa praticar uma conduta, uma sanção deve ser atribuída não à essa pessoa, mas a uma outra. Exemplos desse fenômeno 
formulação da proposição jurídica é identificada pelo próprio Kelsen como "a norma jurídica em sua forma primária". Por outro lado, "a norma que determina a conduta que evita a coação só pode valer como norma jurídica secundária" ${ }^{27}$

O conceito de dever jurídico é determinado com base na norma primária: "um ser humano está obrigado a determinado comportamento na medida em que o oposto desse comportamento é estabelecido na norma jurídica como condição para um ato de coação qualificado como consequência do ato antijurídico" ${ }^{28}$ Essa ligação entre pressuposto e consequência jurídicas constitui a imputação. ${ }^{29}$

são, segundo Kelsen, casos como o daquele em que a família do assassino responde pelo ato praticado por ele, o príncipe responde pelo delito de seus súditos e o povo responde por infrações praticadas por órgãos estatais o que, segundo Kelsen, acontece nos casos de responsabilidade coletiva (KELSEN, Reine Rechtslehre, 1. Auflage, p. 27.

27 KELSEN, Reine Rechtslehre, 1. Auflage, p. 30-31. A partir dessas considerações sobre a norma secundária, Kelsen reconhece que pode haver uma espécie de negação ou até mesmo de contradição envolvida no conceito de antijuridicidade, pois, de fato, a antijuridicidade (a prática da conduta que leva à sanção) se opõe de algum modo à norma secundária (a norma que determina que não se deve praticar a conduta que leva à sanção). Contudo, Kelsen afirma que essa contradição não é uma contradição lógica, pois não pode existir uma contradição lógica entre uma proposição que enuncia um dever ser e uma proposição que enuncia um ser, mas somente entre duas proposições de dever ser ou entre duas proposições de ser. Por isso, afirma Kelsen, a espécie de contradição envolvida no conceito de antijuridicidade, mesmo quando se considera a norma secundária, é um contradição de um tipo diverso do tipo lógico, uma contradição que pode ser teleológica, sobretudo quando se aceita um télos como finalidade objetiva da norma (KELSEN, Reine Rechtslehre, 1. Auflage, p. 31).

28 KELSEN, Reine Rechtslehre, 1. Auflage, p. 46.

29 Segundo Kelsen, "Do mesmo modo que a lei da natureza conecta um determinado fato como causa a outro como efeito, também a lei jurídica conecta a condição jurídica com a consequência jurídica (ou seja, com a consequência do denominado ato antijurídico). Em um caso a forma de conexão dos fatos é a causalidade, no outro é a imputação, que é reconhecida pela teoria pura do direito como a legalidade específica do direito" (KELSEN, Reine Rechtslehre, 1. Auflage, p. 33). 
Ainda na primeira edição da Teoria Pura do Direito, Kelsen destaca que "toda proposição jurídica deve necessariamente estabelecer um dever jurídico, podendo também estabelecer uma autorização (Berechtigung)" ${ }^{30}$ Por outro lado, uma autorização (Berechtigung) existe, segundo Kelsen, quando a norma jurídica condiciona a aplicação da sanção a uma manifestação da vontade da pessoa cujos interesses foram lesados. Essa manifestação de vontade pode ocorrer por meio de queixa ou reclamação, tornando-se então "direito subjetivo". Na visão de Kelsen, o direito subjetivo, como autorização, não é algo independente do direito objetivo, pois aquele existe quando determinado por este. ${ }^{31}$

Além dos já mencionados casos de autorização (direito privado e direito administrativo), Kelsen menciona o direito político, que é um tipo de autorização conferida ao povo, no caso das democracias indiretas, para votar em representantes, bem como aos próprios representantes para participar na produção de normas gerais. Portanto, seja no âmbito da produção de normas individuais ou no âmbito da produção de normas gerais, o direito subjetivo é autorização, possuindo, assim, um caráter secundário em relação à noção de dever, e sendo dele completamente dependente. ${ }^{32}$

30 KELSEN, Reine Rechtslehre, 1. Auflage, p. 48.

31 A autorização é, para Kelsen, uma técnica típica do capitalismo, na medida em que protege o interesse ligado à propriedade privada, não estando contudo presente em todas as áreas do sistema jurídico capitalista, mas apenas em algumas, como o direito privado e determinadas partes do direito administrativo. No direito penal, segundo Kelsen, na medida em que um órgão estatal, na qualidade de autor, põe em movimento o processo de aplicação da sanção, não há de se falar em direito subjetivo. Assim, para a Teoria Pura do Direito, o direito subjetivo existe apenas em alguns casos, e, quando existe, é uma parte constitutiva da individualização da norma, ou seja, da produção de uma norma individual - por exemplo, uma sentença (KELSEN, Reine Rechtslehre, 1. Auflage, p. 48-49).

32 KELSEN, Reine Rechtslehre, 1. Auflage, p. 49-51. 


\subsection{O Direito e a Estrutura das Normas Jurídicas na}

\section{Teoria Geral do Direito e do Estado}

É preciso, antes de entrar na investigação da tipologia das normas jurídicas desenvolvida por Kelsen na Teoria Geral do Direito e do Estado, publicada em 1945, abordar a questão terminológica referente aos conceitos e à distinção entre norma jurídica e proposição jurídica nessa obra. Como vimos acima, Kelsen já havia distinguido expressamente, em 1941, no ensaio A Teoria Pura do Direito e a Jurisprudência Analítica, normas e proposições jurídicas. ${ }^{33} \mathrm{Na}$ Teoria Geral do Direito e do Estado essa distinção será reafirmada, porém, através do uso de outra terminologia: a proposição que descreve normas jurídicas é denominada "regra de direito".

Kelsen abre a Teoria Geral do Direito e do Estado afirmando que o direito é um sistema de "regras":

“O Direito é uma ordem da conduta humana. Uma 'ordem' é um sistema de regras. O Direito não é, como às vezes se diz, uma regra. É um conjunto de regras que possui o tipo de unidade que entendemos por sistema". ${ }^{34}$

Nessa passagem parece evidente que a palavra "regra" (em inglês, rule) corresponde àquilo que Kelsen, em alemão, denomina "norma" (Norm), ou seja, um comando (dever ser), o objeto da ciência do direito, aquilo que a ciência do direito descreve. Há outras passagens da Teoria Geral do Direito e do Estado em que regra jurídica e norma jurídica parecem ser sinônimos, como, por exemplo: "uma regra jurídica proíbe o roubo, prescrevendo que todo ladrão deve ser punido pelo juiz". ${ }^{35}$ Além disso, Kelsen atribui à "regra jurídica" o predi-

33 KELSEN, The Pure Theory of Law and Analytical Jurisprudence, p. 51.

34 KELSEN, General Theory of Law and State, p. 3; KELSEN, Teoria Geral do Direito e do Estado, p. 5. 
cado "válida", 36 o que reforça a conclusão de que a expressão "regra jurídica" indica, nessas passagens, a norma jurídica. Contudo, mais à frente, Kelsen afirma que a "regra jurídica" é a proposição da ciência do direito que descreve seu objeto, as normas jurídicas:

A tarefa da ciência do direito é descrever o direito de uma comunidade, isto é, o material produzido pela autoridade jurídica no procedimento legislativo, na forma de enunciados no sentido de que 'se tais e tais condições não forem satisfeitas, então deve-se proceder a tal e tal sanção'. Esses enunciados, por meio dos quais a ciência do direito descreve o direito, não devem ser confundidos com as normas criadas pelas autoridades legislativas. É preferível não chamar de normas esses enunciados, mas de regras jurídicas. As normas jurídicas decretadas pelas autoridades legislativas são prescritivas; as regras de direito formuladas pela ciência do direito são descritivas. É importante que o termo 'regra jurídica' ou 'regra de direito' seja empregado aqui em um sentido descritivo. (grifos acrescidos) ${ }^{37}$

Portanto, "regra de direito" ou "regra jurídica", que no início da Teoria Geral do Direito e do Estado tinha sido identificada com a norma jurídica, nessa passagem significa aquilo que, em alemão, Kelsen irá, na $2^{a}$ edição da Teoria Pura do Direito, denominar "Rechtssatz", ou seja, " proposição jurídica". O emprego da expressão "regra jurídica" para se referir à "proposição jurídica" não parece adequado, mesmo na língua inglesa, pois a expressão "regra de direito" transmite muito mais a ideia de um comando que a ideia de uma proposição que descreve um comando. É preciso porém considerar que a Teoria Geral do Direito e do Estado constitui uma tradução e síntese de obras antes publicadas

Direito e do Estado, p. 35.

36 KELSEN, General Theory of Law and State, p. 30; KELSEN, Teoria Geral do Direito e do Estado, p. 35.

37 KELSEN, General Theory of Law and State, p. 45; KELSEN, Teoria Geral do Direito e do Estado, p. 49 (tradução alterada). 
por Kelsen em outras línguas. ${ }^{38}$ Além disso, o problema da equivocidade do termo é amenizado porque, como vimos, Kelsen se refere a essa descrição feita pela ciência do direito como regra de direito "em sentido descritivo".

Assim, pode-se concluir haver dois sentidos para a expressão regra de direito na Teoria Geral do Direito e do Estado: um prescritivo, em que regra de direito é sinônimo de norma jurídica, e outro descritivo, em que regra de direito designa a proposição da ciência do direito que descreve a norma jurídica. Feita essa observação, a estrutura e tipologia das normas nessa obra pode ser abordada.

Kelsen afirma que estar juridicamente obrigado a praticar uma conduta significa que a conduta contrária é condição de uma sanção e, por isso, "o dever jurídico não é nada quando separado da norma jurídica" ${ }^{39}$ Segundo o próprio Kelsen, essa definição de dever jurídico significa que a norma jurídica que estabelece o dever de uma pessoa, ligando a uma conduta uma sanção, não necessariamente estabelece um dever de a autoridade aplicar a sanção. A aplicação da sanção será um dever somente quando uma norma adicional vincular uma sanção à não aplicação da primeira sanção. Para que o órgão que aplica a segunda norma tenha o dever de aplicá-la é preciso uma terceira norma, que estabeleça uma sanção caso esse órgão não aplique a sanção.$^{40}$ Kelsen

38 A Teoria Geral do Direito e do Estado constitui, como afirma Kelsen no prefácio, uma reformulação de "ideias e pensamentos previamente expressos em alemão e em francês", sobretudo na Teoria Geral do Estado (1925), na Teoria Geral do Direito Internacional Público, publicada em francês, em 1928, e na $1^{\text {a }}$ edição da Teoria Pura do Direito (1934). A tradução da parte principal do livro é de Anders Wedberg, mas, como afirma Kelsen no prefácio da obra, ele próprio a revisou (KELSEN, General Theory of Law and State, p. XIII e XVIII; KELSEN, Teoria Geral do Direito e do Estado, p. XXVII e XXXIV.

39 KELSEN, General Theory of Law and State, p. 59; KELSEN, Teoria Geral do Direito e do Estado, p. 64 (tradução alterada).

40 KELSEN, General Theory of Law and State, p. 59-60; KELSEN, Teoria Geral do 
reconhece que essa série não pode ir ao infinito, e, por isso, afirma que "deve haver uma norma última da série, uma norma tal que a sanção por ela capitulada não seja um dever jurídico no sentido [ali] definido" ${ }^{41}$

Na visão de Kelsen, no âmbito da moral, o conceito de "dever" coincide com o conceito de "dever ser", pois a conduta que constitui o dever moral de uma pessoa é a conduta prescrita pela norma. No direito, porém, embora o dever jurídico implique um dever ser, o dever jurídico não pode ser definido como a conduta que a norma exige, mas antes como "a conduta por meio de cuja observância o delito é evitado" ${ }^{42}$ Segundo Kelsen, "apenas a sanção deve ser executada". ${ }^{43}$

Exatamente aqui entra em jogo o conceito de norma secundária. Na visão de Kelsen, a fim de se afirmar que o dever jurídico deve ser executado, deve-se dividir a norma jurídica em duas normas, dois enunciados de dever ser: um primeiro enunciado (ou uma primeira norma) que determina que uma pessoa "deve" observar uma certa conduta e um segundo enunciado (ou uma segunda norma) que determina que outra pessoa deve executar uma sanção caso a primeira norma seja violada. ${ }^{44}$ Repetindo ideias presentes em obras anteriores, ele afirma então que caso se admita que a primeira norma só é válida quando uma outra (a segunda)

Direito e do Estado, p. 64.

41 KELSEN, General Theory of Law and State, p. 60; KELSEN, Teoria Geral do Direito e do Estado, p. 64.

42 KELSEN, General Theory of Law and State, p. 61; KELSEN, Teoria Geral do Direito e do Estado, p. 65.

43 KELSEN, General Theory of Law and State, p. 61; KELSEN, Teoria Geral do Direito e do Estado, p. 65.

44 KELSEN, General Theory of Law and State, p. 61; KELSEN, Teoria Geral do Direito e do Estado, p. 65. Kelsen cita como exemplo dessa divisão as seguintes normas: "não se deve roubar; se alguém roubar, será punido". 
vincula uma sanção à condição nela estabelecida (no caso do exemplo citado pelo próprio Kelsen, vincula uma sanção ao roubo), a primeira norma é, em uma "exposição jurídica rigorosa", supérflua. Nas palavras de Kelsen: "a primeira norma, se é que ela existe, está contida na segunda, a única norma jurídica genuína". ${ }^{45}$

Kelsen reconhece, contudo, que a exposição do direito é facilitada através da exposição da primeira norma. Contudo, em sua opinião, só é legítimo fazer essa exposição quando se tem a "consciência de que a primeira norma, que exige a omissão do delito, depende da segunda norma, que estipula a sanção" ${ }^{46}$ Em virtude dessa dependência, a segunda norma, que, como vimos, é a "genuína" norma jurídica, é denominada, por Kelsen, norma primária, como nos escritos anteriores, e a primeira norma é denominada secundária, também como nos escritos anteriores. ${ }^{47}$ Em síntese, nas próprias palavras de Kelsen, “o direito é a norma primária que estipula a sanção". ${ }^{48}$

Ainda na Teoria Geral do Direito e do Estado, Kelsen ressalta que quando se define o delito meramente como conduta antijurídica, o direito é considerado um sistema de normas secundárias, o que não é, contudo, sustentável, pois o direito é uma ordem coativa que estipula sanções. Quando porém se considera o direito como um conjunto de normas primárias, ele (o direito) não é violado pelo delito do sujeito:

45 KELSEN, General Theory of Law and State, p. 61; KELSEN, Teoria Geral do Direito e do Estado, p. 65.

46 KELSEN, General Theory of Law and State, p. 61; KELSEN, Teoria Geral do Direito e do Estado, p. 65.

47 KELSEN, General Theory of Law and State, p. 61; KELSEN, Teoria Geral do Direito e do Estado, p. 65.

48 No original "the law"; na versão em português aparece "à lei". KELSEN, General Theory of Law and State, p. 45; KELSEN, Teoria Geral do Direito e do Estado, p. 65. 
“apenas o órgão pode agir contra o direito em si, contra a norma primária, ao não executar a sanção, apesar de suas condições terem sido concretizadas." 49

Por fim, Kelsen diferencia "obediência" e "aplicação" do direito. Quando se considera o direito como um conjunto de normas primárias, somente o órgão pode "obedecer" ou "desobedecer" à norma (ou ao direito), pois somente ele pode executar ou não executar a sanção. $\mathrm{O}$ sujeito pode, segundo Kelsen, apenas "obedecer" ou "desobedecer" à norma secundária. Kelsen observa, porém, que na linguagem ordinária geralmente se afirma que o sujeito "obedece" ou "desobedece" à norma jurídica. ${ }^{50}$ Assim, para se evitar confusão, é útil, segundo Kelsen, adotar uma terminologia que reflita a diferença entre a relação do direito com o sujeito que pratica o delito e com o órgão que aplica a sanção. Por isso, ele propõe adotar a seguinte terminologia: o sujeito, ao praticar a conduta que evita a sanção, obedece ao direito (e, naturalmente, ao praticar a conduta que leva à execução da sanção desobedece ao direito), enquanto o órgão que executa a sanção aplica o direito. ${ }^{51}$

49 KELSEN, General Theory of Law and State, p. 61; KELSEN, Teoria Geral do Direito e do Estado, p. 65 (tradução alterada).

50 No original: "the legal norm"; na versão em português: “à lei". KELSEN, General Theory of Law and State, p. 61; KELSEN, Teoria Geral do Direito e do Estado, p. 66.

51 KELSEN, General Theory of Law and State, p. 61; KELSEN, Teoria Geral do Direito e do Estado, p. 66. É interessante notar que a Teoria Geral do Direito $e$ do Estado contém ainda a posição de Kelsen sobre a ideia de permissão. Partindo da clássica afirmação de que o direito imperativo diria respeito às normas jurídicas que comandam ou proíbem, enquanto o direito permissivo (no original: "imperative law" e "permissive law"; na versão em português: "lei imperativa" $\mathrm{e}$ "lei permissiva") diria respeito às normas jurídicas que permitem, Kelsen conclui que essa distinção não é válida, pois a ordem jurídica, ao dar a permissão a uma pessoa, conferindo a ela um direito, impõe um dever a outra pessoa. Em outros termos, o direito impõe um direito através de uma sanção e, por isso, segundo Kelsen, “o 
Por fim, cumpre notar que, na Teoria Geral do Direito e do Estado, Kelsen aborda o conceito de "direito jurídico em sentido estrito", que corresponde ao que ele antes abordou sob a denominação "direito subjetivo" ${ }^{52}$ Kelsen apresenta as mesmas ideias que já haviam aparecido na primeira edição da Teoria Pura do Direito. Primeiramente, assim como nas obras anteriores, ele rejeita a teoria do interesse..$^{53}$ Após isso, ele se refere ao "direito jurídico" (legal right) - ou seja, ao direito subjetivo - como um poder, afirmando que nem toda norma jurídica que estabelece um dever de um indivíduo em relação a outro ${ }^{54}$ confere ao segundo um direito jurídico sobre o primeiro, ou seja, nem sempre a ordem jurídica condiciona a aplicação da sanção a uma manifestação de vontade da parte. ${ }^{55}$ Ele também reafirma que o direito jurídico (o direito subjetivo) pode ser compreendido como a participação na criação do direito (objetivo), seja no âmbito do direito privado ou do direito público, sendo que, neste, geralmente é designado pela expressão "direitos políticos". ${ }^{56}$

direito é imperativo para um e, desse modo, permissivo para outro" (no original: "the law is imperative for the one, and thereby permissive for other"; na versão em português: "a lei é imperativa para um e, desse modo, permissiva para outro") (KELSEN, General Theory of Law and State, p. 77; KELSEN, Teoria Geral do Direito e do Estado, p. 81).

52 Há, aqui, clara influência da terminologia anglo-saxã na escolha do termo.

53 KELSEN, General Theory of Law and State, p. 79-81; KELSEN, Teoria Geral do Direito e do Estado, p. 83-85.

54 KELSEN, General Theory of Law and State, p. 81; KELSEN, Teoria Geral do Direito e do Estado, p. 85.

55 KELSEN, General Theory of Law and State, p. 82; KELSEN, Teoria Geral do Direito e do Estado, p. 86.

56 KELSEN, General Theory of Law and State, p. 87-88; KELSEN, Teoria Geral do Direito e do Estado, p. 90-91. 


\subsection{A Estrutura das Normas Jurídicas na Versão Fran-}

\section{cesa da Primeira Edição da Teoria Pura do Direito}

Na versão francesa da primeira edição da Teoria Pura do Direito, publicada em 1953, Kelsen repete uma vez mais a ideia, presente na primeira edição alemã, de que os juristas do século XIX já tinham identificado que o direito é uma ordem coativa, ${ }^{57}$ ou seja, uma técnica social que realiza sua tarefa ligando um ato coativo à conduta contrária à conduta desejada.

Como o direito é uma ordem coativa, nem todos os elementos que estão presentes em uma norma são relevantes. A norma fundamental ${ }^{58}$ da ordem jurídica determina que se uma condição determinada conforme a primeira constituição se realize, um ato de coação determinado da mesma maneira deve ser realizado. ${ }^{59}$ Assim, afirma Kelsen, se uma constituição afirma que "os homens nascem livres e iguais entre eles", ${ }^{60}$ ou que "o objetivo do estado é garantir a felicidade dos cidadãos", ${ }^{61}$ ou ainda se um juiz declara, em uma sentença, "que ele considera sua decisão justa ou que ele tem o dever de proteger os pobres contra os ricos", ${ }^{62}$ isso não tem qualquer relação com a norma fundamental da

57 KELSEN, Théorie Pure du Droit, p. 62.

58 A norma fundamental constitui um dos temas mais polêmicos da obra de Kelsen. Não é possível abordá-la mais de perto aqui. Para uma análise de seu conceito e de sua evolução cf. WALTER, Robert, Entstehung und Entwicklung des Gedankens der Grundnorm; PAULSON, Stanley L., Die Funktion der Grundnorm: begründend oder explizierend?; JESTAEDT, Matthias, Geltung des Systems und Geltung im System; TRAVESSONI GOMES [TRIVISONNO], O Fundamento de Validade do Direito - Kant e Kelsen.

59 KELSEN, Théorie Pure du Droit, p. 65.

60 KELSEN, Théorie Pure du Droit, p. 65.

61 KELSEN, Théorie Pure du Droit, p. 65.

62 KELSEN, Théorie Pure du Droit, p. 65. 
ordem jurídica, e a ciência do direito não é capaz de atribuir a isso um sentido jurídico objetivo. ${ }^{63}$ Em outros termos, na visão de Kelsen, afirmações como essa, ainda que contidas no material jurídico positivo, são elementos juridicamente irrelevantes.

Kelsen aborda os conceitos de norma primária e secundária em seção especificamente dedicada ao tema. Ele afirma que a única norma jurídica completa, que contém todos os elementos necessários, ${ }^{64}$ é a norma que define tanto a condição para que seja aplicada uma sanção quanto essa sanção, como, por exemplo, a norma "aquele que não realizar o serviço militar obrigatório deve ser condenado a uma pena de prisão entre dois e cinco anos". ${ }^{65}$ Segundo Kelsen, uma norma que simplesmente estabeleça a obrigação de se prestar serviço militar, sem indicar a sanção atribuída à violação dessa obrigação, é uma norma incompleta, não podendo portanto ser considerada uma verdadeira norma jurídica. ${ }^{66}$ Kelsen então afirma:

“Damos à norma que estabelece a relação entre o fato ilícito e a sanção o nome de norma primária, e denominamos norma secundária aquela que prescreve a conduta que torna possível evitar a sanção. Paralelamente, a ciência do direito descreve esses dois tipos de normas formulando regras de direito primárias ou secundárias, mas uma regra de direito secundária é de fato supérflua, pois ela pressupõe a existência de uma regra de direito primária sem a qual ela não teria qualquer significado jurídico, e essa regra de direito primária contém todos os elementos necessários para a descrição da norma jurídica completa." ${ }^{67}$

Essa passagem possui extrema importância, por duas razões. Primeiramente, porque ela sintetiza com precisão

63 KELSEN, Théorie Pure du Droit, p. 66.

64 KELSEN, Théorie Pure du Droit, p. 67.

65 KELSEN, Théorie Pure du Droit, p. 67.

66 KELSEN, Théorie Pure du Droit, p. 67.

67 KELSEN, Théorie Pure du Droit, p. 65. 
o núcleo da teoria de Kelsen sobre a estrutura das normas jurídicas, a saber, que a norma completa é a norma primária que liga o ato de coação como sanção a um pressuposto, e ainda que a norma secundária é supérflua. Em segundo lugar, ela evidencia que Kelsen, novamente, diferencia com clareza a proposição que descreve normas jurídicas das próprias normas jurídicas, sendo aquela denominada "regra de direito". Portanto, a expressão "regra de direito" foi usada para designar a proposição jurídica não só na língua inglesa (como vimos acima, legal rule na Teoria Geral do Direito e do Estado, 1945), mas também em francês. Novamente aqui vale o comentário já realizado sobre o emprego do termo regra de direito na Teoria Geral do Direito e do Estado: a terminologia é infeliz. Mas, também aqui, trata-se de uma obra traduzida. ${ }^{68}$ Como veremos adiante, em alemão, que era sua língua materna, Kelsen passará a denominar o enunciado que descreve as normas jurídica, sobretudo a partir da segunda edição da Teoria Pura do Direito, como "proposição jurídica" (Rechtssatz).

A passagem citada evidencia ainda que, uma vez que existem normas primárias (completas) e normas secundárias (incompletas, supérfluas), haverá proposições da ciência do direito descrevendo ambas (as "regras de direito" nesse sentido específico). Assim, as proposições que descrevem as normas secundárias seriam supérfluas, sobretudo diante das proposições que descrevem as normas primárias.

Kelsen afirma ainda que não se pode deduzir logicamente da "regra de direito" secundária a "regra de direito" primária, como se faz, por exemplo, quando se passa da pro-

68 A versão francesa da $1^{\mathrm{a}}$ edição da Teoria Pura do Direito, traduzida por Henri Thévenaz, não é, como afirma o próprio Kelsen no prefácio da obra, uma mera tradução, pois vários pontos foram reformulados (cf. KELSEN, Théorie Pure du Droit) 
posição "todos os homens são mortais" à conclusão "Paulo é mortal". Isso porque, segundo Kelsen, há identidade entre as regras de direito primária e secundária: a obrigação de prestar serviço militar não se deduz portanto logicamente de uma "regra de direito" primária que determina a punição dos soldados que não prestam serviço militar. ${ }^{69}$ Para Kelsen,

“a primeira [regra de direito que determina a obrigação de se prestar serviço militar] exprime exatamente a mesma ideia que a segunda [a regra de direito que determina a punição dos soldados que não prestam serviço militar], e essa identidade é consequência de nossa definição de direito, que consideramos como uma ordem de coação, e de nossa definição de regra de direito, que vemos como uma proposição que afirma que sob certas condições um ato de força deve ser realizado a título de sanção". ${ }^{70}$

\subsection{A Teoria Abrangente da Estrutura das Normas Ju- rídicas na Segunda Edição da Teoria Pura do Direito}

Na segunda edição da Teoria Pura do Direito, publicada em 1960, Kelsen mantém a ideia de que a norma que ele havia até então denominado primária, ou seja, a norma que estatui um ato de coação como sanção, é a verdadeira (ou, como afirma Kelsen nessa obra, autêntica) norma jurídica. Entretanto, ele não mais a denomina norma primária. Além disso, ele reafirma que a norma que enuncia um dever, norma que ele antes havia denominado secundária, é supérflua, mas não mais emprega o termo que antes havia usado para designá-la, ou seja, ela não é mais denominada norma secundária, sendo antes considerada um tipo de norma não-autônoma.

A tipologia que Kelsen desenvolve na segunda edição da Teoria Pura do Direito é mais completa que as anteriores, incluindo, como veremos, outros tipos de norma. A meu ver,

69 KELSEN, Théorie Pure du Droit, p. 67.

70 KELSEN, Théorie Pure du Droit, p. 67-68. 
pode-se afirmar que Kelsen desenvolve, nessa obra, uma teoria mais ampla sobre a estrutura das normas jurídicas, que denominarei "teoria abrangente da estrutura das normas jurídicas". Porém, antes de entrar na investigação dessa teoria, é preciso abordar a distinção expressa entre norma e proposição jurídica.

A distinção entre norma jurídica (Rechtsnorm) e proposição jurídica (Rechtssatz), embora já apareça no primeiro capítulo da obra, ${ }^{71}$ é desenvolvida de forma sistemática apenas no terceiro capítulo, dedicado ao direito e à ciência. Nesse capítulo, Kelsen afirma que a ciência do direito descreve as normas jurídicas produzidas por atos humanos e que devem ser aplicadas e observadas também por atos humanos. Segundo Kelsen, essa descrição é feita através de "proposições jurídicas" (Rechtssätze), que devem ser distinguidas das normas jurídicas que são produzidas por órgãos jurídicos com a finalidade de serem aplicadas e observadas pelos destinatários do direito. ${ }^{72}$ As proposições jurídicas são, segundo Kelsen, juízos hipotéticos que enunciam que, mediante determinadas condições ou pressupostos fixados pelo ordenamento jurídico, devem ocorrer determinadas consequências estabelecidas por esse mesmo ordenamento. As normas jurídicas, segundo Kelsen, não são juízos, ou seja, "enunciados sobre determinado objeto", mas "comandos e, como tais, ordens, imperativos. Mas não são apenas comandos, pois também são permissões e atribuições de poder ou competência". ${ }^{73}$ É interessante notar que essa conceituação

71 Por exemplo, ao tratar das normas não-autônomas, Kelsen afirma que a proposição jurídica é aquela com a qual a ciência do direito descreve seu objeto (KELSEN, Reine Rechtslehre, 2. Auflage, p. 58; KELSEN, Teoria Pura do Direito, $2^{\mathrm{a}}$ ed., p. 61).

72 KELSEN, Reine Rechtslehre, 2. Auflage, p. 73; KELSEN, Teoria Pura do Direito, $2^{a}$ ed., p. 78.

73 KELSEN, Reine Rechtslehre, 2. Auflage, p. 73; KELSEN, Teoria Pura do Direito, 
da norma como imperativo é diferente daquela apresentada em Principais Problemas. Como vimos acima, em Principais Problemas Kelsen havia rejeitado a identificação da norma como imperativo, pois um imperativo seria a expressão imediata de uma vontade psicológica, o que uma norma não é. ${ }^{74} \mathrm{~A}$ aceitação de que a norma pode ser conceituada como imperativo pode ter relação com uma progressiva mudança de posição de Kelsen em relação à distinção entre norma e proposição jurídica: normas são postas por atos de vontade, enquanto proposições jurídicas (que descrevem normas) são atos de conhecimento. Essa distinção que, como vimos nos escritos iniciais de Kelsen, não é tão clara, passa a ficar cada vez mais nítida em sua obra.

Feita essas observações, posso agora passar à tipologia das normas jurídicas na segunda edição da Teoria Pura do Direito. Assim como nas obras anteriores, o direito e, com isso, as normas jurídicas autênticas são, para Kelsen, normas que estabelecem sanções. A imputação jurídica, que se distingue da causalidade da natureza, consiste exatamente nessa ligação entre pressuposto e consequência através de um "dever ser". Na visão de Kelsen, quando a conduta que condiciona a sanção é praticada, então é devida a sanção, o que significa que a conduta que condiciona a sanção é proibida e a conduta oposta é comandada (prescrita). Por isso, afirma Kelsen, a conduta comandada (prescrita) não é devida; devida é a sanção. A execução da sanção é comandada se e na medida em que sua omissão constitui o pressuposto de uma outra norma que liga a essa omissão uma sanção. Se essa segunda norma não existir, há apenas atribuição de poder (Ermächtigung $)^{75}$

\section{$2^{\text {a }}$ ed., p. 79 (tradução alterada).}

74 KELSEN, Hauptprobleme der Staatsrechtslehre, p. 210.

75 No original aparece: "kann sie [die Sanktion] nur als ermächtigt [...]", o que foi traduzido, na edição em língua portuguesa, como: "ela [a sanção] 
para a aplicação da sanção, o que significa que ela não é comandada (prescrita). Após isso, Kelsen afirma, como já havia feito antes, que uma vez que esse regresso não pode ir ao infinito, só pode haver uma atribuição de poder $^{76}$ para a aplicação da última sanção dessa série, ou seja, essa aplicação não pode ser comandada (prescrita). ${ }^{77}$

Kelsen ressalta, como nas obras anteriores, que as ordens jurídicas têm como característica essencial o fato de possuírem atos de coação como sanção, ${ }^{78}$ o que não significa, contudo, "que em todos os casos de sua efetivação se tenha de empregar a coação física. Isso só deverá suceder quando essa efetivação encontrar resistência, o que não é normalmente o caso" ${ }^{79}$

Kelsen mantém, aqui, sua "doutrina" de que não há deveres jurídicos sem sanção. ${ }^{80}$ Normas jurídicas prescrevem condutas, isto é, obrigam ou estabelecem deveres jurídicos, através da ligação, a determinados fatos condicionantes, de atos de coação como sanção. Mas isso não significa, segun-

pode ser apenas autorizada" (cf. KELSEN, Reine Rechtslehre, 2. Auflage, p. 26; KELSEN, Teoria Pura do Direito, $2^{\text {a }}$ ed., p. 28). De fato o verbo ermächtigen pode ser traduzido como "autorizar". Mas isso gera certa confusão, pois o substantivo Ermächtigung teria que ser então traduzido como "autorização", o que levaria a uma confusão com o conceito de Berechtigung, que, como vimos, também pode ser traduzido como "autorização", mas não constitui uma função normativa, estando antes ligado ao conceito de direito subjetivo, como vimos acima. Por essa razão, emprego, aqui, as seguintes traduções: "atribuir poder" para ermächtigen e "atribuição de poder" para Ermächtigung; Berechtigung é traduzida como "autorização".

76 Cf. nota 73.

77 KELSEN, Reine Rechtslehre, 2. Auflage, p. 26; KELSEN, Teoria Pura do Direito, $2^{\text {a }}$ ed., p. 28.

78 KELSEN, Reine Rechtslehre, 2. Auflage, p. 34; KELSEN, Teoria Pura do Direito, $2^{\text {a }}$ ed., p. 36.

79 KELSEN, Reine Rechtslehre, 2. Auflage, p. 35; KELSEN, Teoria Pura do Direito, $2^{\text {a }}$ ed., p. 37.

80 KELSEN, Reine Rechtslehre, 2. Auflage, p. 51-55; KELSEN, Teoria Pura do Direito, $2^{\text {a }}$ ed., p. 54-58. 
do Kelsen, que todas as normas jurídicas sejam normas que possuam um ato de coação como sanção. ${ }^{81}$

Kelsen admite a existência de outras normas ao lado da norma jurídica que estabelece um ato de coação como sanção. Essas normas são "normas jurídicas não-autônomas". ${ }^{82}$ Segundo Kelsen, quando uma norma comanda uma determinada conduta e uma segunda norma estatui uma sanção para a hipótese de não observância da primeira, essas normas estão intimamente ligadas. A primeira norma estabelece, apenas negativamente, o pressuposto ao qual a segunda norma liga a sanção. Para Kelsen, na medida em que a segunda norma estabelece, positivamente, o pressuposto que é negativamente estabelecido pela primeira, a primeira - ou seja, aquela que estabelece negativamente o pressuposto ao qual a outra norma liga uma sanção - torna-se supérflua do ponto de vista da técnica legislativa: “'não-matarás' é supérflua quando vigora uma norma que reza: 'quem matar será punido'. ${ }^{83}$ Essa norma (não matarás), que nos trabalhos anteriores tinha sido denominada por Kelsen como "norma secundária", é agora denominada uma norma não-autônoma, assim como não-autônomas são também, segundo ele, as normas que permitem positivamente uma conduta, limitando a validade de uma norma que proíbe uma conduta, ${ }^{84}$ as normas que

81 Embora não aceite a existência de deveres jurídicos sem sanção, Kelsen considera, como já havia feito em obras anteriores, a possibilidade de a ciência do direito não ser capaz de interpretar determinados conteúdos do material normativo positivo como norma jurídica objetivamente válida, quando, por exemplo, uma passagem da constituição estabelece que o direito provém de Deus (KELSEN, Reine Rechtslehre, 2. Auflage, p. 54; KELSEN, Teoria Pura do Direito, $2^{\text {a }}$ ed., p. 57).

82 KELSEN, Reine Rechtslehre, 2. Auflage, p. 55-59; KELSEN, Teoria Pura do Direito, $2^{\text {a }}$ ed., p. 59-62.

83 KELSEN, Reine Rechtslehre, 2. Auflage, p. 56; KELSEN, Teoria Pura do Direito, $2^{a}$ ed., p. 59.

84 As normas que permitem positivamente uma conduta são normas que 
suprimem completamente a validade de outras normas, ${ }^{85}$ as normas que conferem competência ${ }^{86}$ e as normas que determinam com maior exatidão o sentido de outras normas. ${ }^{87}$

limitam o domínio de validade de uma norma que pró́be uma conduta. Kelsen cita, novamente, o exemplo da legítima defesa, desta vez se referindo ao artigo $2^{\circ}, \mathrm{n}^{\circ} 4$ da Carta das Nações Unidas, que proíbe aos estados membros o uso da força, na medida em que liga a esse uso da força as sanções do artigo 39, e o artigo 51, que permite o uso da força como autodefesa individual ou coletiva, "limitando assim a proibição geral do artigo $2^{\circ \prime}$ (KELSEN, Reine Rechtslehre, 2. Auflage, p. 56; KELSEN, Teoria Pura do Direito, 2a ed., p. 59-60).

85 Elas não meramente "limitam" o domínio da validade de outra norma, mas lhe retiram completamente a validade. Essas normas, que Kelsen denomina "derrogatórias", são também não-autônomas, na medida em que só podem ser compreendidas em conexão com normas que estabelecem sanções (KELSEN, Reine Rechtslehre, 2. Auflage, p. 58; KELSEN, Teoria Pura do Direito, $2^{\mathrm{a}}$ ed., p. 61).

86 As normas que atribuem competência, ou seja, conferem poder a um indivíduo para produzir normas jurídicas, são também, na visão de Kelsen, normas não-autônomas. Elas podem conferir poderes a uma autoridade para produzir normas gerais, como as normas da constituição que regulamentam o processo legislativo, ou podem conferir poderes a determinadas autoridades para a produção de normas jurídicas individuais (órgãos administrativos e jurisdicionais) (KELSEN, Reine Rechtslehre, 2. Auflage, p. 57-58; KELSEN, Teoria Pura do Direito, 2a ed., p. 60-61). Elas são normas não-autônomas, porque determinam pressupostos e condições de aplicação das normas que estabelecem sanções. Autônoma é apenas a norma que estabelece o ato de coação a ser aplicado quando esses (e outros) pressupostos ocorram (KELSEN, Reine Rechtslehre, 2. Auflage, p. 58; KELSEN, Teoria Pura do Direito, $2^{\mathrm{a}}$ ed., p. 61).

87 As normas que determinam com maior exatidão o sentido de outras normas são também, segundo Kelsen, normas não-autônomas. Trata-se de normas que definem um conceito que aparece em outras normas, o que constitui, na terminologia usual, interpretação autêntica. Kelsen menciona o exemplo da norma que define o homicídio como a conduta pela qual um indivíduo provoca intencionalmente a morte de outro e que, em sua visão, só possui caráter normativo em conexão com a norma que determina que se um indivíduo pratica homicídio ele deve ser punido, por exemplo, com a pena de morte (KELSEN, Reine Rechtslehre, 2. Auflage, p. 58; KELSEN, Teoria Pura do Direito, $2^{\text {a }}$ ed., p. 62). 
Em síntese, há, aqui, dois tipos de normas jurídicas: (i) a norma autêntica, que é aquela que liga um ato de coação a um pressuposto, e (ii) todas as demais, que são denominadas não-autônomas. Estas podem ser de cinco tipos: (ii.a) normas que enunciam o dever, que são supérfluas, normas que (ii.b) estabelecem poder, (ii.c) permitem positivamente, (ii.d) derrogam ou (ii.e) interpretam outras normas. Estas quatro últimas não são supérfluas. O quadro abaixo sintetiza essa tipologia:

\begin{tabular}{|c|c|c|}
\hline \multicolumn{2}{|c|}{ Teoria Pura do Direito (2a ed.) (1960) } & Observações \\
\hline \multicolumn{2}{|c|}{$\begin{array}{c}\text { norma autêntica: liga um ato de coação } \\
\text { como sanção a determinado pressupos- } \\
\text { to fático }\end{array}$} & $\begin{array}{l}\text { pode ser também deno- } \\
\text { minada autônoma; } 88 \text { antes } \\
\text { denominada "primária" }\end{array}$ \\
\hline \multirow{5}{*}{$\begin{array}{l}\text { normas } \\
\text { não- } \\
\text { autônomas }\end{array}$} & $\begin{array}{c}\text { norma que enuncia o de- } \\
\text { ver }\end{array}$ & $\begin{array}{l}\text { é supérflua; antes deno- } \\
\text { minada "secundária" }\end{array}$ \\
\hline & $\begin{array}{l}\text { norma que permite positi- } \\
\text { vamente: limita a aplicação } \\
\text { de outra norma }\end{array}$ & não é supérflua \\
\hline & $\begin{array}{l}\text { norma que derroga: supri- } \\
\text { me completamente a apli- } \\
\text { cação de outra norma }\end{array}$ & não é supérflua \\
\hline & $\begin{array}{l}\text { norma que estabelece po- } \\
\text { der ou competência }\end{array}$ & não é supérflua \\
\hline & $\begin{array}{c}\text { norma que interpreta ou- } \\
\text { tras normas }\end{array}$ & não é supérflua \\
\hline
\end{tabular}

Kelsen ressalta que, embora nem todas as normas jurí-

88 Em virtude do fato de todas as demais serem denominadas "não-autônomas".

89 Ao "interpretar" outras normas esse tipo de norma está, na verdade, estabelecendo condições - muitas vezes novas condições, ainda não previstas na norma interpretada - para aplicação de outras normas. $\mathrm{O}$ próprio Kelsen parece reconhecer isso; assim, elas talvez pudessem ser 
dicas estabeleçam atos de coação como sanção, o direito pode ser caracterizado como uma ordem de coação, pois aquelas normas que não o fazem estabelecem condições mediante as quais atos de coação são aplicados. Isso deve ser descrito pela proposição jurídica, que, como vimos acima, aparece, na segunda edição da Teoria Pura do Direito, claramente como a proposição formulada pela ciência do direito, cuja função é descrever normas jurídicas. ${ }^{90}$

denominadas "normas que estabelecem condições para a aplicação de outras normas".

90 KELSEN, Reine Rechtslehre, 2. Auflage, p. 59; KELSEN, Teoria Pura do Direito, $2^{\mathrm{a}}$ ed., p. 62. Na seção dedicada ao dever jurídico, localizada no Capítulo IV, que estuda a estática jurídica, Kelsen explica que dizer que um indivíduo tem o dever de se conduzir de determinada maneira é a mesma coisa que dizer que a conduta é comandada (prescrita), ou que o indivíduo é obrigado a praticá-la. E se o direito é concebido como uma ordem coativa, uma conduta só pode ser considerada comandada, isto é, só pode ser considerada conteúdo de um dever, quando uma norma jurídica liga à conduta oposta um ato de coação como sanção. Segundo Kelsen, o dever jurídico não pode ser identificado apenas com o dever jurídico geral, como faz a teoria tradicional, podendo ter um caráter geral ou individual, conforme a norma jurídica que o prescreve (KELSEN, Reine Rechtslehre, 2. Auflage, p. 120-121; KELSEN, Teoria Pura do Direito, 2a ed., p. 128-129). Ao conceito de dever jurídico está ligado, segundo Kelsen, o conceito de responsabilidade, abordado em seção autônoma. Nessa abordagem, Kelsen ressalta, como já havia feito na primeira edição da Teoria Pura do Direito, que o indivíduo a quem a norma dirige a sanção não é necessariamente o indivíduo cuja conduta é o pressuposto do ato de coação. Quando a ordem jurídica dirige a sanção ao indivíduo cuja conduta é o pressuposto do ato de coação ele responde pelo ato antijurídico próprio. Quando, porém, a ordem jurídica dirige a sanção a um indivíduo diverso daquele cuja conduta é o pressuposto do ato de coação, este responde por um delito cometido por outro (KELSEN, Reine Rechtslehre, 2. Auflage, p. 125; KELSEN, Teoria Pura do Direito, 2a ed., p. 132-133). Segundo Kelsen, podese designar essa responsabilização por delito praticado por outro como responsabilidade coletiva. Porém, o termo responsabilidade coletiva pode ser usado ainda, também segundo Kelsen, quando a sanção se dirige não contra um indivíduo, mas contra um grupo, como no caso das sanções do direito primitivo, que eram dirigidas não contra o indivíduo que praticou a conduta mas contra o grupo ao qual ele pertence, ou ainda as sanções do direito internacional, como a represália e a guerra (KELSEN, Reine 
Por fim, cumpre ressaltar que Kelsen não só mantém sua crítica ao conceito de direito subjetivo, como a amplia. Ele rejeita, uma vez mais, as teorias da vontade e do interesse, e afirma que o direito subjetivo é o reflexo do dever jurídico de alguém em outrem ou uma autorização para produção de normas jurídicas no âmbito do direito privado ou público (sendo que, no caso deste último, trata-se dos direitos políticos). A exposição integral dessa crítica extrapolaria porém os limites deste trabalho. ${ }^{91}$

\subsection{A Confirmação da Estrutura das Normas Jurídicas}

\section{na Teoria Geral das Normas}

Na Teoria Geral das Normas, publicada em 1979, portanto após a morte de Kelsen, ele adota exatamente a mesma posição defendida nas obras anteriores: a norma juridicamente relevante é aquela que liga o ato de coação a um pressuposto, sendo a norma que enuncia o dever supérflua. Nessa obra, Kelsen volta a designar a autêntica norma jurídica como "primária" e a norma que enuncia o dever como "secundária".

Kelsen afirma que os destinatários imediatos das normas jurídicas gerais hipotéticas são os indivíduos autorizados (e eventualmente obrigados) a aplicar a sanção, enquanto os indivíduos cujas condutas constituem condições de aplicação desses atos de coação são destinatários mediatos. ${ }^{92}$ Após isso ele menciona a possibilidade de se conceber o direito como união de dois tipos de normas: aquelas que estabelecem como devida uma certa conduta e aquelas que determinam que certos atos de coação devem ser ligados por

Rechtslehre, 2. Auflage, p. 127; KELSEN, Teoria Pura do Direito, $2^{\mathrm{a}}$ ed., p. 135).

91 KELSEN, Reine Rechtslehre, 2. Auflage, p. 131-145; KELSEN, Teoria Pura do Direito, $2^{\text {a }}$ ed., p. 139-153

92 KELSEN, Allgemeine Theorie der Normen, p. 40; KELSEN, Teoria Geral das Normas, p. 64. 
um órgão judicial à violação da primeira. Ele afirma então ter designado a primeira como secundária e a segunda como primária. Após isso, Kelsen explora a dualidade norma primária/norma secundária no âmbito tanto das normas gerais quanto das normas individuais. Sintetizando os conceitos de direito, dever e sanção, ele afirma:

Costuma-se diferenciar entre normas jurídicas que impõem uma conduta determinada e normas jurídicas que ligam uma sanção à conduta contra essas normas, como para diferenciar entre normas jurídicas primárias e secundárias, como, porventura: não se deve furtar; se alguém furta, deve ser punido. Mas a formulação da primeira de ambas as normas é supérflua, dado que o não-dever-furtar juridicamente só existe no dever-ser-punido ligado à condição do furto. A moral impõe uma conduta não por ligar uma sanção à conduta contrária à norma. Aqui estão duas normas integrantemente ao lado uma da outra, como, p. ex.: 'Não se deve mentir'. 'Deve-se desaprovar a mentira, deve-se aprovar a omissão da mentira. ${ }^{93}$

Essa passagem revela que, na Teoria Geral das Normas, Kelsen continua considerando a norma jurídica que enuncia o dever supérflua quando existe uma norma jurídica que liga uma sanção a determinado pressuposto condicionante. Para Kelsen, isso só não vale para a moral, que seria uma ordem em que normas primárias e secundárias existiriam umas ao lado das outras. Mais adiante, Kelsen volta à diferença entre normas da moral e do direito, afirmando:

Se se admite que a distinção de uma norma que prescreve a uma conduta determinada e de uma norma que prescreve uma sanção para o fato da violação da primeira seja essencial para o Direito, então precisa-se qualificar a primeira como norma primária e a segunda como secundária - e não o contrário, como foi por mim anteriormente formulado. A norma primária pode, pois, aparecer inteiramente independente da norma secundária. Mas é também possível que uma norma expressamente formulada, a primeira,

93 KELSEN, Allgemeine Theorie der Normen, p. 108; KELSEN, Teoria Geral das Normas, p. 171. 
i. e., a norma que impõe uma conduta determinada geralmente não apareça, e apenas apareça a norma secundária, i. e., a norma que estabelece a sanção. Desta forma formulam-se reiteradamente normas jurídicas nas modernas leis. ${ }^{94}$

A partir dessa passagem, José Florentino Duarte, tradutor da Teoria Geral das Normas para a língua portuguesa, conclui que Kelsen teria alterado a posição que adotou durante praticamente toda sua vida profissional: ele teria passado a defender que a norma primária não mais seria a norma que liga um ato de coação como sanção a determinado pressuposto condicionante, mas sim a norma que estabelece o dever que o indivíduo deve praticar, e, consequentemente, que a norma secundária não mais seria a norma que enuncia o dever, mas antes a norma que liga a sanção a determinado pressuposto. Essa posição é, a meu ver, equivocada, pois na passagem em que Duarte se baseia - passagem que acabo de reproduzir acima - Kelsen não está apresentando sua posição, mas antes levantando uma hipótese: "se se admite que a distinção de uma norma que prescreve a uma conduta determinada e de uma norma que prescreve uma sanção para o fato da violação da primeira seja essencial para o direito" 95 (grifos acrescidos) deve a primeira ser denominada primária e a segunda secundária. Mas Kelsen não admite isso, ou seja, para Kelsen, essa distinção não era e não continua sendo essencial. Uma evidência textual comprova isso. No parágrafo que aparece imediatamente após a passagem reproduzida acima Kelsen afirma:

O moderno legislador do direito não diz: 1. 'Não se deve furtar' e 2. 'Se alguém furta deve ser punido com cadeia, ou: 1 . 'Deve-se pagar um empréstimo recebido' e 2. 'Se alguém não paga um

94 KELSEN, Allgemeine Theorie der Normen, p. 115; KELSEN, Teoria Geral das Normas, p. 181.

95 No original em alemão: "nimmt man an, daß [...]" ( KELSEN, Allgemeine Theorie der Normen, p. 115). 
empréstimo recebido, deve ser dirigida uma execução em seu patrimônio', mas ele se limita, comumente, a estabelecer a norma que liga ao furto a sanção da pena de prisão, ou o não pagamento de um empréstimo recebido a sanção de execução forçada.

A expressa formulação da norma que proíbe o furto e da norma que impõe o pagamento de um empréstimo recebido, i. e., a norma que prescreve a conduta que evita a sanção, é efetivamente supérflua, pois está - como já indicado anteriormente - implicada na norma que estatui a sanção. Pois a norma que estatui um ato de coação como sanção aparece como norma primária e a nela implicada que, de modo algum é expressamente formulada, e não precisa ser expressamente formulada, aparece como norma secundária. Nisto se expressa o decisivo papel que a sanção existente num ato de coação desempenha no Direito como uma ordem de coação. A estatuição desta sanção é tão essencial que se pode dizer: o Direito impõe uma conduta determinada somente por ligar à conduta contrária um ato de coação como sanção, de modo que uma certa conduta somente depois que juridicamente 'imposta' pode ser considerada como conteúdo de um 'dever jurídico', quando o oposto é a condição à qual uma norma liga uma sanção. ${ }^{96}$

Nessa passagem Kelsen não está falando hipoteticamente. Nela ele está apresentando sua opinião, que é exatamente a mesma defendida nas obras anteriores: a norma jurídica que enuncia o dever é supérflua quando uma norma liga um ato de coação a um pressuposto condicionante, e essa norma que estatui a sanção é a norma primária.

Além das normas jurídicas primárias e secundárias, Kelsen admite que outras normas fazem parte do ordenamento jurídico. Sem usar a expressão normas não-autônomas, que, como vimos, ele havia empregado na segunda edição da Teoria Pura do Direito, Kelsen se refere às seguintes funções da norma jurídica: impor, permitir, autorizar e derrogar. ${ }^{97}$ Não é possível, aqui, descrever a análise de Kelsen

96 KELSEN, Allgemeine Theorie der Normen, p. 115; KELSEN, Teoria Geral das Normas, p. 181-182.

97 KELSEN, Allgemeine Theorie der Normen, p. 76-92; KELSEN, Teoria Geral das 
sobre essas funções normativas. Cumpre apenas destacar que essas funções correspondem aos tipos de normas que Kelsen já havia indicado na segunda edição da Teoria Pura do Direito: a função impor é a função da norma autêntica - a norma primária -, enquanto as funções permitir, autorizar e derrogar são funções de normas que Kelsen havia denominado, na segunda edição da Teoria Pura do Direito, não-autônomas.

\section{Síntese da Teoria da Estrutura das Normas Jurídicas de Kelsen}

Percebe-se, portanto, que embora tenha havido evolução, a teoria de Kelsen sobre a estrutura das normas jurídicas não se modificou em sua essência. A norma jurídica autêntica sempre foi, para Kelsen, a norma hipotética que liga a um pressuposto fático uma consequência, um ato de coação como sanção. Ela é hipotética porque contém um pressuposto fático (se A ocorre - ou se A é) que é ligado a uma consequência jurídica (a sanção $B$ que é um ato de coação), através de um "dever ser" (se A é, deve ser B). Deveres jurídicos são, ao longo de toda obra de Kelsen, estabelecidos por essas normas autênticas (normas primárias), o que faz que normas que meramente enunciam um dever (normas secundárias) sejam supérfluas ou precisem ser conectadas, para que tenham algum sentido como normas jurídicas, a normas que estabelecem sanções para sua violação.

Ao longo de sua obra, Kelsen sistematiza progressivamente suas ideias, adicionando a sua teoria sobre a estrutura das normas jurídicas tipos de normas que ele antes não havia caracterizado. Assim, por exemplo, na segunda edição da Teoria Pura do Direito, aparecem, além da norma autêntica (a norma que liga um ato de coação a determinado pressu-

Normas, p. 120-145. 
posto - norma que Kelsen havia denominado antes norma primária), vários tipos de normas "não-autônomas": a norma que enuncia o dever (que antes ele havia denominado norma secundária), a norma que permite positivamente, a norma que derroga, a norma que estabelece poder ou competência e a norma que interpreta. $O$ fato de esses quatro últimos tipos de normas (que permitem positivamente, que derrogam, que estabelecem poderes e que interpretam outras normas) não aparecerem expressamente nos escritos anteriores de Kelsen não quer dizer, porém, que ele não concebia a possibilidade da existência de normas que desempenhem essas funções. Kelsen menciona essas funções em seus escritos iniciais, sem, porém, atribuir a cada uma delas um respectivo tipo de norma específica, e sem tratá-las em conjunto em uma seção específica de uma obra, como fez na segunda edição da Teoria Pura do Direito. ${ }^{98}$ Nesse sentido, a teoria contida na segunda edição da Teoria Pura do Direito constitui, a meu ver, a mais completa e elaborada versão da teoria da estrutura das normas de Kelsen.

Há, portanto, uma evolução, marcada muito mais pela sistematização e aglutinação de conceitos que por mudanças essenciais. O quadro abaixo evidencia essa evolução, bem como a correspondência entre as ideias de Kelsen sobre a estrutura das normas nas suas principais obras:

98 Assim, a atribuição de poder aparece, por exemplo, quando Kelsen aborda a estrutura escalonada da ordem jurídica (cf. KELSEN, Reine Rechtslehre, 1. Auflage, Capítulo V), bem como, na Teoria Geral do Direito e do Estado, quando ele aborda a "competência", em capítulo próprio (cf. KELSEN, General Theory of Law and State; KELSEN, Teoria Geral do Direito e do Estado, Capítulo V). A derrogação é abordada no âmbito da análise de conflitos de normas (cf. KELSEN, General Theory of Law and State; KELSEN, Teoria Geral do Direito e do Estado, Capítulo XI, ponto H). Muitos outros exemplos poderiam ser citados; o importante é ressaltar, uma vez mais, que, apenas na segunda edição da Teoria Pura do Direito, Kelsen aborda uma teoria abrangente da estrutura das normas jurídicas. 


\begin{tabular}{|c|c|c|c|c|c|c|}
\hline 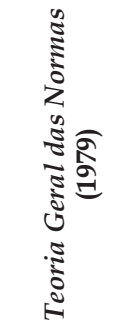 & 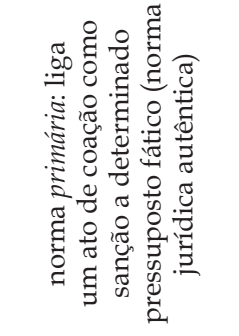 & 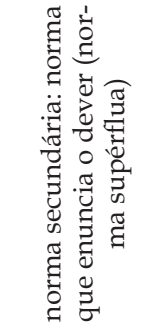 & 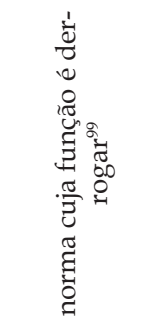 & 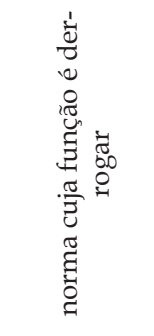 & 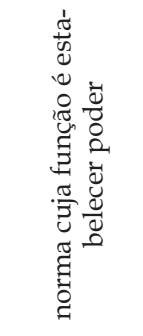 & 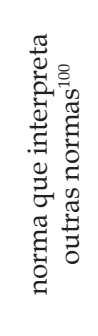 \\
\hline 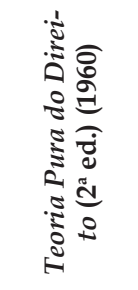 & 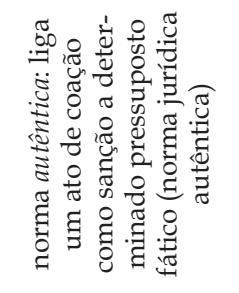 & 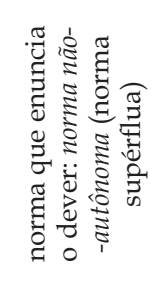 & 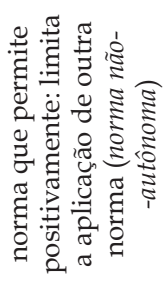 & 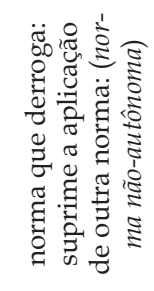 & 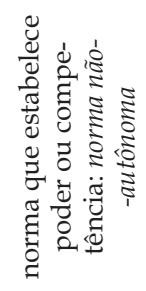 & 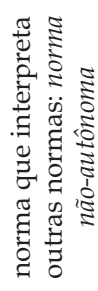 \\
\hline 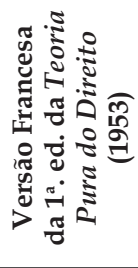 & 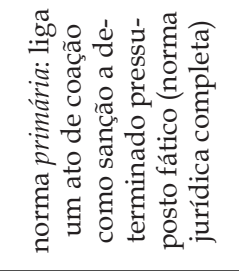 & 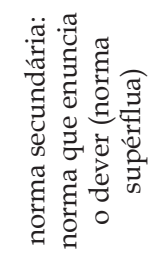 & \multicolumn{4}{|c|}{ 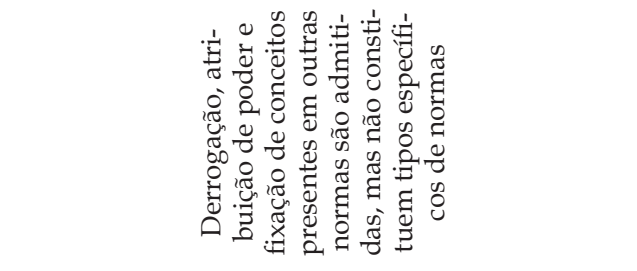 } \\
\hline 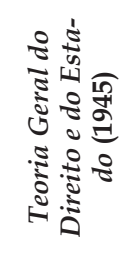 & 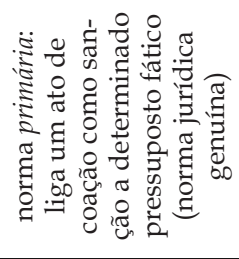 & 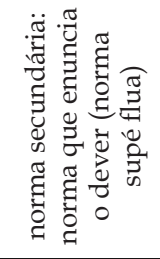 & \multicolumn{4}{|c|}{ 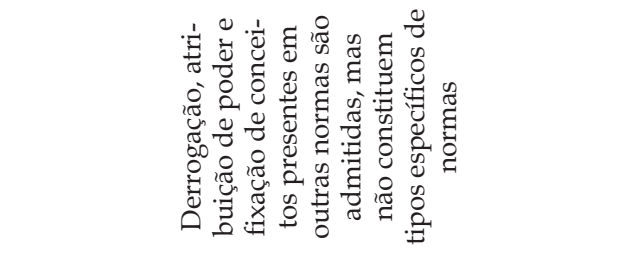 } \\
\hline 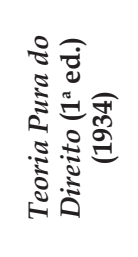 & 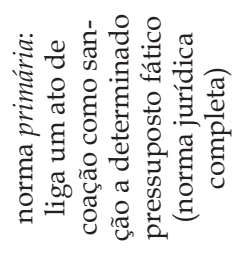 & 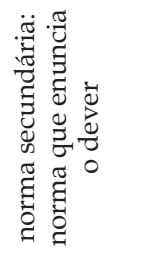 & \multicolumn{4}{|c|}{ 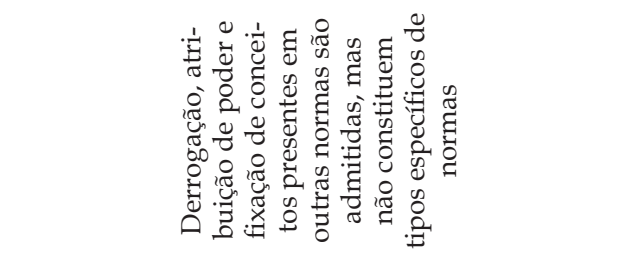 } \\
\hline 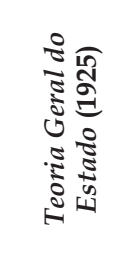 & 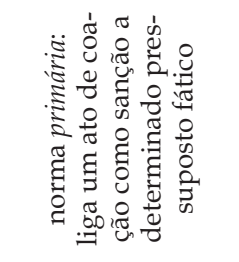 & 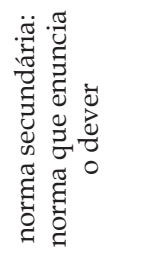 & \multicolumn{4}{|c|}{ 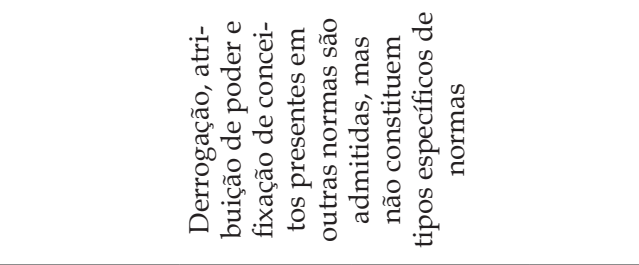 } \\
\hline 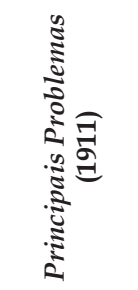 & 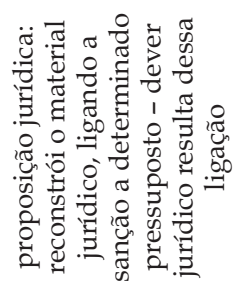 & 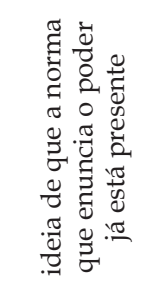 & \multicolumn{4}{|c|}{ 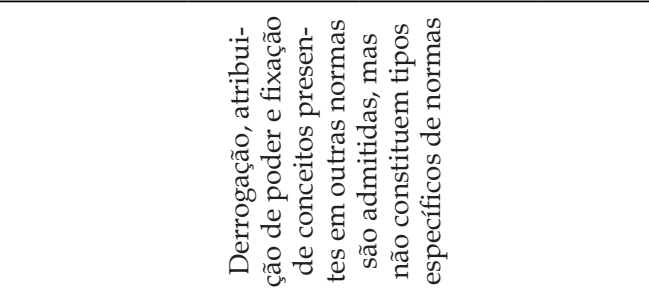 } \\
\hline
\end{tabular}




\section{A Teoria da Estrutura das Normas Jurídicas de Kelsen e os Tipos de Regras Jurídicas em Hart}

Concluído o estudo da evolução da teoria da estrutura das normas de Kelsen, cabe fazer uma breve comparação entre sua teoria e a de Hart. Essa comparação é muito importante, sobretudo para evitar confusões terminológicas que podem decorrer da falta de atenção ao fato dos termos "primária" e "secundária" terem sentidos diferentes em Kelsen e em Hart.

Assim, o objetivo desta seção não é fazer uma comparação profunda entre as teorias de Kelsen e Hart sobre a estrutura das normas, mas antes apenas apresentar distinções básicas. Em sua obra $O$ Conceito de Direito, Hart afirma, em síntese, que o direito pode ser considerado um sistema de regras primárias e secundárias (primary and secondary rules). ${ }^{101}$ Regras primárias são, para Hart, aquelas que estabelecem deveres, possuindo sanção e coação. ${ }^{102}$ Mas o sistema jurídico não pode ser constituído apenas por elas pois, caso fosse, haveria três problemas fundamentais: em primeiro lugar, incerteza, gerada pela ausência de regras determinando o que é direito, ${ }^{103}$ em segundo lugar, um caráter estático das regras, ${ }^{104}$ devida à ausência de regras estabelecendo formas

99 A permissão positiva passa a ser vista, na Teoria Geral das Normas, como derrogação, pois Kelsen passa a considerar não haver distinção entre suprimir parcialmente a validade (limitar) e suprimir totalmente a validade de uma norma.

100 Interpretar não constitui, na Teoria Geral das Normas, uma função autônoma, mas Kelsen menciona, nessa obra, normas que interpretam outras normas.

101 Cf. HART, The Concept of Law, p. 79-99.

102 Cf. HART, The Concept of Law, Cap. IV.

103 Cf. HART, The Concept of Law, p. 92.

104 Cf. HART, The Concept of Law, p. 92-93. 
deliberadas de mudança das mesmas e, por fim, uma ineficiência da pressão social difusa, ${ }^{105}$ que a ausência de regras estabelecendo formas de aplicação geraria. Para superar esses problemas, existentes quando o direito é concebido apenas como um conjunto de regras primárias, Hart sugere a introdução de três tipos de regras, que ele denomina regras secundárias: regras que determinam (i) como se reconhece quais são as regras jurídicas de determinada comunidade, (ii) como se criam e modificam regras jurídicas e, por fim, (iii) como elas são aplicadas. ${ }^{106} \mathrm{~A}$ regra do primeiro tipo, que é uma só para cada sistema jurídico, foi denominada pelo próprio Hart como "regra de reconhecimento" (rule of recognition) ${ }^{107}$ As regras do segundo tipo são denominadas "regras de mudança" (rules of change) ${ }^{108} \mathrm{e}$, por fim, as do terceiro tipo são denominadas, em tradução literal, "regras de adjudicação" (rules of adjudication), ${ }^{109}$ que aqui serão denominadas porém "regras de aplicação".

As regras secundárias do segundo e do terceiro tipos, ou seja, as regras secundárias de modificação e de aplicação, apresentam-se em grande número nos modernos sistemas jurídicos. Trata-se, de modo geral, nos modernos estados de direito, das regras que estabelecem poderes e procedimentos de produção, modificação e aplicação das leis. São exemplos de regras secundárias de modificação as regras disciplinando o processo legislativo, enquanto as regras processuais seriam exemplos das regras secundárias de aplicação.

\footnotetext{
105 Cf. HART, The Concept of Law, p. 93-94.

106 Cf. HART, The Concept of Law, p. 94-95.

107 Cf. HART, The Concept of Law, p. 94.

108 Cf. HART, The Concept of Law, p. 95.

109 Cf. HART, The Concept of Law, p. 95. Essa expressão poderia também ser traduzida como "regras que conferem jurisdição".
} 
A regra de reconhecimento é a o critério supremo e a regra última do sistema (supreme criterion and ultimate rule), 110 porque as outras regras são reconhecidas como regras jurídicas com base nela (critério supremo) e porque ela não pode ser derivada de outra regra (regra última). Ela pode ser mais ou menos complexa, ${ }^{111}$ mas sempre estabelece quais são os requisitos para se considerar determinados fatos como direito. ${ }^{112}$

Muito mais poderia ser dito aqui, mas isso extrapolaria o escopo deste trabalho. Cabe agora, como anunciado acima, fazer uma breve comparação entre as teorias de Kelsen e Hart sobre a estrutura das normas jurídicas. Para fins dessa comparação, usarei a teoria exposta por Kelsen na segunda edição da Teoria Pura do Direito, com apenas uma modificação: usarei o termo "norma primária" (termo que, como vimos, Kelsen usou ao longo de sua obra mas não empregou na segunda edição da Teoria Pura do Direito) para me referir à norma autêntica que liga um ato de coação a um pressuposto e o termo "norma secundária" (termo que, como também vimos, Kelsen usou ao longo de sua obra mas não empregou na segunda edição da Teoria Pura do Direito) para me referir à norma supérflua que enuncia o dever.

A regra primária de Hart parece corresponder à norma primária de Kelsen, pois ambas são padrões que estabelecem deveres e sanções coativas. Duvidoso é, porém, se a regra primária de Hart corresponde somente à norma primária de Kelsen ou também à norma secundária de Kelsen. Hart não faz uma distinção analítica - como aquela feita por Kelsen

110 Cf. HART, The Concept of Law, p. 105-107.

111 Cf. HART, The Concept of Law, p. 95.

112 A regra de reconhecimento do sistema inglês seria "o que estatui a rainha no parlamento é direito" ("what the queen in parliament enacts is law") (HART, The Concept of Law, p. 107). 
- entre a norma que liga o ato de coação como sanção a um pressuposto normativo (norma primária de Kelsen) e a norma que enuncia o dever (norma secundária de Kelsen). Para ele, normas que estabelecem deveres e possuem coação são normas primárias. Como, para Kelsen, a norma secundária diz a mesma coisa que a primária, sendo - exatamente por isso - supérflua, pode-se dizer que a regra primária de Hart corresponde às normas primária e secundária de Kelsen, ou, mais precisamente, a regra primária de Hart corresponde à norma primária de Kelsen e, por isso, corresponde também à norma secundária de Kelsen.

Mas quais normas de Kelsen correspondem às regras secundárias de Hart? Como vimos acima, são três os tipos de regras secundárias em Hart: (i) regra secundária de reconhecimento, (ii) regras secundárias de modificação e (iii) regras secundárias de aplicação. O segundo e o terceiro tipos de regras secundárias de Hart, regras de modificação e regras de aplicação, identificam-se claramente com as normas não-autônomas que estabelecem poderes de Kelsen. Poder-se-ia pensar, aqui, ser a teoria de Hart mais analítica que a de Kelsen, exatamente por distinguir dois tipos de normas de poder (ou que atribuem poderes), o que Kelsen não faz. Mas isso não procede. A falta dessa distinção em Kelsen não decorre de uma falta de atenção analítica, mas antes de uma consciente concepção, por parte de Kelsen, de que entre legislação e jurisdição não há uma distinção essencial, mas antes uma distinção de grau. Ambas, legislação e jurisdição, constituem ao mesmo tempo produção e aplicação do direito: no caso da legislação a aplicação da constituição para produção de normas gerais e, no caso da jurisdição, aplicação das leis para produção de normas individuais. ${ }^{113}$

113 Cf., por exemplo, KELSEN, Reine Rechtslehre, 1. Auflage, p. 82-83; KELSEN, Reine Rechtslehre, 2. Auflage, VIII; KELSEN, Teoria Pura do Direito, 2ª ed., VIII. 
Assim, para Kelsen, não faria sentido distinguir normas de modificação e normas de aplicação. Por fim, cumpre ressaltar que a regra de reconhecimento de Hart não possui correspondência com nenhuma norma positiva em Kelsen, mas antes com a norma fundamental, que Kelsen concebeu como uma norma pressuposta, acima das normas positivas, e que confere validade ao ordenamento jurídico. O quadro abaixo expressa a relação entre as duas teorias: ${ }^{114}$

\begin{tabular}{|c|c|c|}
\hline & Teoria de Kelsen & Teoria de Hart \\
\hline \multicolumn{2}{|c|}{$\begin{array}{l}\text { normas primárias: ligam um ato de coação } \\
\text { como sanção a determinado pressuposto } \\
\text { fático }\end{array}$} & \multirow{2}{*}{$\begin{array}{l}\text { regras primárias: esta- } \\
\text { belecem } \\
\text { deveres e sanções coa- } \\
\text { tivas }\end{array}$} \\
\hline \multirow{5}{*}{$\begin{array}{l}\text { normas } \\
\text { não- } \\
\text { autônomas }\end{array}$} & $\begin{array}{c}\text { normas secundárias: normas } \\
\text { que enunciam deveres }\end{array}$ & \\
\hline & $\begin{array}{l}\text { normas que permitem positi- } \\
\text { vamente: limitam a aplicação } \\
\text { de outras normas }\end{array}$ & vacat \\
\hline & $\begin{array}{l}\text { normas que derrogam: supri- } \\
\text { mem a aplicação de outras } \\
\text { normas }\end{array}$ & vacat \\
\hline & $\begin{array}{l}\text { normas que estabelecem po- } \\
\text { der ou competência }\end{array}$ & $\begin{array}{c}\text { regras secundárias de } \\
\text { modificação } \\
\text { regras secundárias de } \\
\text { aplicação }\end{array}$ \\
\hline & $\begin{array}{l}\text { normas que interpretam ou- } \\
\text { tras normas }\end{array}$ & vacat \\
\hline \multicolumn{2}{|c|}{$\begin{array}{l}\text { em termos de direito positivo, vacat: não } \\
\text { existe correspondente, na tipologia de } \\
\text { normas jurídico-positivas de Kelsen, à } \\
\text { regra de reconhecimento de Hart; mas ela } \\
\text { corresponde, na teoria de Kelsen como um } \\
\text { todo, à norma fundamental }\end{array}$} & $\begin{array}{l}\text { regra secundária de } \\
\text { reconhecimento }\end{array}$ \\
\hline
\end{tabular}

114 Ao "interpretar" outras normas esse tipo de norma está, na verdade, 
Duas observações finais devem ser feitas. Em primeiro lugar, a correspondência entre a norma fundamental de Kelsen e a regra de reconhecimento de Hart pode ser contestada, pois o próprio Hart rejeita ser a regra de reconhecimento uma regra "pressuposta" ${ }^{115}$ Porém, aqui não se afirma identidade entre a regra de reconhecimento de Hart e a norma fundamental de Kelsen, mas antes "correspondência", o que significa que elas possuem meramente função semelhante: tornar possível o reconhecimento de determinados fatos como direito.

Em segundo lugar, poderia ser feita um crítica à teoria de Hart em virtude de sua suposta deficiência em relação à teoria de Kelsen, por dois motivos: (i) a teoria de Kelsen é mais completa, pois abrange normas que a teoria de Hart não abrange, pois as normas que permitem positivamente, que derrogam e que interpretam não estão presentes em sua tipologia e (ii) a teoria de Kelsen contém uma distinção analítica importante que a teoria de Hart não contem: a distinção entre a norma que enuncia o dever e a norma que estabelece $o$ ato de coação.

Não é possível, aqui, avaliar com profundidade, a correção ou não dessa possível crítica. Em defesa de Hart cabe apenas ressaltar que, em relação ao primeiro aspecto - a completude -, o próprio Hart expressamente afirmou que, ao conceber o direito como conjunto de regras primárias e secundárias, não tinha pretensão de desenvolver um modelo

estabelecendo condições - muitas vezes novas condições, ainda não previstas na norma interpretada - para aplicação de outras normas. $\mathrm{O}$ próprio Kelsen parece reconhecer isso; assim, elas talvez pudessem ser denominadas "normas que estabelecem condições para a aplicação de outras normas".

115 Sem se referir nominalmente a Kelsen, Hart afirma que alguns autores consideram essa regra última do sistema como uma regra pressuposta, mas rejeita essa caracterização (Cf. HART, The Concept of Law, p. 108-110). 
que abrangesse todas as normas do sistema jurídico, ou seja, não pretendia desenvolver uma teoria abrangente. ${ }^{116} \mathrm{Em}$ relação ao segundo aspecto, a falta da divisão analítica de sua regra primária em duas sub-regras, uma que enuncia o dever e outra que estabelece a sanção, parece decorrer do fato de Hart, ao contrário de Kelsen, não pretender identificar o direito como uma ordem coativa, mas sim, pelo contrário, combater essa noção. ${ }^{117}$

\section{Conclusão: a Importância da Teoria da Estru- tura das Normas Jurídicas de Kelsen Ainda Hoje}

O caráter relativamente detalhado da análise feita acima aliada ao aspecto quase evidente da qualidade da teoria de Kelsen fazem com que a conclusão deste ensaio não precise ser longa. Ela reza: Kelsen elaborou uma teoria (i) inovadora, (ii) que foi se ampliando progressivamente ao longo do tempo - mas com coerência - e (iii) que ainda possui grande importância atualmente. Basta, agora, explicar brevemente essas três notas conclusivas. (i) A teoria de Kelsen é inovadora porque, ao concentrar sua atenção na norma jurídica que liga um ato de coação como sanção a determinado pressuposto-a norma primária hipotética - ele de fato inverteu, como ele próprio ressalta já em Principais Problemas, a lógica da ciência do direito do século XIX, que não tinha, como ele próprio também afirma ainda em Principais Problemas, extraído todas as consequências científicas de seus próprios avanços. (ii) Essa teoria foi se ampliando progressivamente, mantendo porém a coerência, pois, como vimos, foram sendo incor-

116 Cf. HART, The Concept of Law, Cap. V

117 Cf. HART, The Concept of Law, Cap. I a IV. 
porados tipos de normas além dos dois tipos fundamentais iniciais (as normas primária e secundária), a ponto de, na segunda edição da Teoria Pura do Direito, Kelsen poder apresentar uma teoria abrangente. Contudo, as ideias essenciais de que a autêntica norma jurídica é aquela que liga um ato de coação como sanção a determinado pressuposto fático e que a norma que enuncia o dever é supérflua se mantiveram inalteradas. (iii) A teoria de Kelsen possui, a meu ver, grande importância ainda hoje, porque ela evidencia que não há dever jurídico sem sanção, sanção essa que precisa ser um ato de coação. Se, por um lado, pode-se questionar a crítica de Kelsen ao conceito de direito subjetivo, afirmando, por exemplo, que o direito subjetivo existe independentemente de uma norma. Por outro lado, é inegável que um direito subjetivo, ao qual não se correlacione um dever jurídico exigível coativamente, possui, quando muito, validade no mundo ideal. Se isso é verdade, o direito subjetivo precisa, de fato - pelo menos no mundo real -, sempre se relacionar a uma norma que estabeleça, em caso de sua violação, um ato de coação como sanção. ${ }^{118}$ Coube a Kelsen mostrar isso, ou seja, coube a ele mostrar que só há direito quando há a possibilidade da coação.

\section{Referências}

HART, Herbert L. A. The Concept of Law. $2^{\text {nd }}$ edition. Oxford: Oxford University Press, 1994.

HEIDEMANN, Carsten. Die Norm als Tatsache - zur Normentheorie Hans Kelsens. Baden-Baden: Nomos Verlag, 1997.

118 Essa parece ser uma constatação da ciência do direito de modo geral. O que a Teoria Pura do Direito faz é explicitar isso de forma clara. Sobre a compatibilidade, nesse ponto, entre a Teoria Pura do Direito e a ciência do direito "tradicional", cf. WALTER, Der Gegenwärtige Stand der Reinen Rechtslehre, p. 77. 
JESTAEDT, Matthias. Geltung des Systems und Geltung im System, in: Juristen Zeitung, 21, 2013, p. 1009-1021.

KELSEN, Hans. Allgemeine Staatslehre. Berlin/Heidelberg/ New York: Springer-Verlag, 1925.

KELSEN, Hans. Allgemeine Theorie der Normen, Kurt Ringhofer/Robert Walter (ed.). Wien: Manzsche Verlag, 1979.

KELSEN, Hans. General Theory of Law and State, Tradução de Anders Wedberg. Cambrigde/Massachusetts: Harvard University Press, 1949.

KELSEN, Hans. Hauptprobleme der Staatsrechtslehre, entwickelt aus der Lehre vom Rechtssatze, 2. Auflage. Tübingen: J.C.B. Mohr, 1923.

KELSEN, Hans. Professor Stone and the Pure Theory of Law, in: Stanford Law Review, 1965, 17, 6, p. 1128-1157.

KELSEN, Hans. Reine Rechtslehre - Einleitung in die Rechtswissenschaftliche Problematik, 1. Auflage. Leipzig/Wien: Franz Deuticke, 1934.

KELSEN, Hans. Reine Rechtslehre, 2. Auflage (Nachdruck), Wien: Österreich Verlag, 2000.

KELSEN, Hans Teoria Geral das Normas, tradução de José F. Duarte. Porto Alegre: Sergio Antônio Frabis Editor, 1986.

KELSEN, Hans. Teoria Geral do Direito e do Estado, tradução de Luís Carlos Borges. São Paulo: Martins Fontes, 2000.

KELSEN, Hans. Teoria Pura do Direito, tradução de J. B. Machado. São Paulo: Martins Fontes, 1987.

KELSEN, Hans. Théorie Pure du Droit. Tradução de Henri Thévenaz. Neuchatel : Éditions de la Baconnière, 1953.

KELSEN, Hans. The Pure Theory of Law and Analytical Jurisprudence, in: Harvard Law Review, 1941 (55), p. 44-70. 
KOJA, Hans Kelsen oder die Reinheit der Rechtslehre. Wien: Böhlau, 1988.

PAULSON, Stanley L. Die Funktion der Grundnorm: begründend oder explizierend?, in: Gedenkschrift Robert Walter, Clemens Jabloner, Dieter Kolonovits, Gabriele Kucsko-Stadlmayer, Hans René Laurer, Heinz Mayer e Rudolf Thienel (orgs). Wien: 2013, p. 553-573.

PAULSON, Stanley L. Four Phases in Kelsen's Pure Theory of Law? in: Oxford Journal of Legal Studies, 1998, 18, 1, p. 153-166.

PAULSON, Stanley L. Kelsen's Legal Theory: the Final Round, in: Oxford Journal of Legal Studies, 1992, 12, 2, p. 265-274.

PAULSON, Stanley L. Reflexões sobre a Periodização da Teoria do Direito de Hans Kelsen - Com Pós-Escrito Inédito, tradução de Júlio Aguiar de Oliveira. in: Hans Kelsen, Teoria Jurídica e Política, Júlio A. De Oliveira e Alexandre T. G. Trivisonno (orgs.). Rio de Janeiro: Forense Universitária, 2013, p. 3-37.

WALTER, Robert. Entstehung und Entwicklung des Gedankens der Grundnorm, in: Schwerpunkte der Reinen Rechtslehre - Schriftenreihe des Hans Kelsen-Instituts, Robert Walter (org.). Wien: Manzsche Verlag und Universitätsbuchhandlung, 1992, p. 47-59.

WALTER, Robert. Der gegenwärtige Stande der Reinen Rechtslehre, in: Rechtstheorie, 1, 1/2, 1970, p. 69-93. 
Recebido em 08/03/2020

Aprovado em 21/08/2020

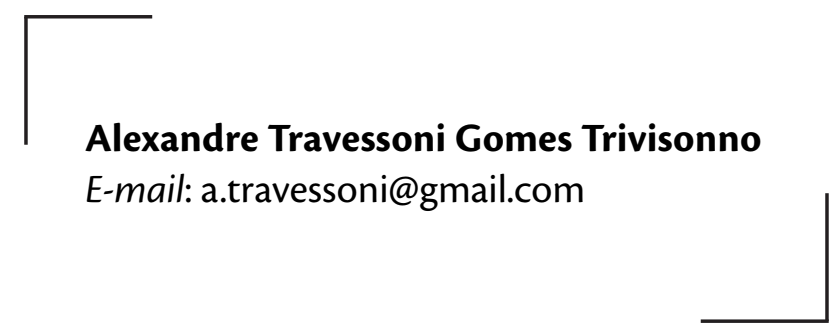

